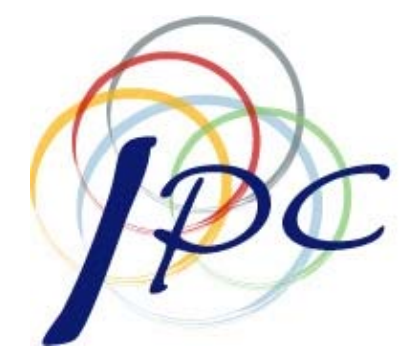

InTERnational Policy Center

Gerald R. Ford School of Public Policy University of Michigan

IPC Working Paper Series Number 73

Does Gender Matter for Firm Performance? Evidence from Eastern Europe and Central Asia

Shwetlena Sabarwal

Katherine Terrell

September, 2008 


\title{
Does Gender Matter for Firm Performance? Evidence from Eastern Europe and Central Asia
}

\author{
Shwetlena Sabarwal* \\ PREM Gender, World Bank \\ and \\ Katherine Terrell \\ PREM Gender, World Bank \\ University of Michigan
}

JEL codes: D24, M21, O12, O16,

Keywords: Entrepreneurship, Finance, Gender, Eastern Europe and Central Asia

Acknowledgements: This paper benefited from presentations at the World Bank Economists' Forum, PREM Learning Week and the Seminar on Poverty and Applied Microeconomics. We would like to thank the ECSPE and PRMGE groups at the World Bank for supporting this research and the following individuals for discussions that improved the paper: Elena Bardasi, Zuzana Brixiova, Paul Cichello, Stepan Jurajda, Leora Klapper, David McKenzie, Andrew Morrison, Fernanda Ruiz Núñez and Jan Svejnar.

*This paper was prepared as a part of the background research for an ECA regional report titled 'Sharing the Growth Dividend: Women in the ECA Region'. 


\begin{abstract}
Using 2005 firm level data for 26 countries in eastern and Central Europe, this paper estimates performance gaps between male and female-owned businesses, while controlling for location by industry and country. The findings show that female entrepreneurs have a significantly smaller scale of operations (as measured by sales revenues) and are less efficient in terms of total factor productivity, although the difference is small. However, women entrepreneurs generate the same amount of profit per unit of revenue as men. Although both male and female entrepreneurs in the region are sub-optimally small, women's returns to scale are significantly larger than men's, implying that women would gain more from increasing their scale. The authors argue that the main reasons for the sub-optimal size of female-owned firms are that they are both capital constrained and concentrated in industries with small firms.
\end{abstract}




\section{Introduction}

If women face different conditions and institutional constraints than men; these factors can spill over into their performance in entrepreneurship. A relatively new strand of entrepreneurship research raises the question "Does gender matter?" This paper complements the existing research (which is based largely on the experience of one country in the developed part of the world), with the analysis of entrepreneurial performance by gender in the 26 countries of the Eastern Europe and Central Asia (ECA), a region where there is little information on this topic. We measure relative performance in terms of sales revenues, profits and total factor productivity and we explore economic and institutional explanations for the patterns we observe. In contrast to some of the other studies on gender differences in entrepreneurial performance, this paper explores many dimensions of performance (such as scale, profitability, technical and financial efficiency) and therefore provides a more well rounded and comprehensive analysis of the role of gender in firm performance.

The definition of entrepreneurship in the literature is quite broad, including "selfemployed” individuals (with or without employees), “owners of a firm” and "innovators” (defined in various ways). The operationalization of these definitions is in part circumscribed by data availability, but it is clear that they can reflect very different phenomena. In this paper, we define an entrepreneur as an owner/manager of an individually or family owned firm.

The paper is organized as follows: In Section 2 we review the literature on the relative performance of male and female-owned firms. The data are described in Section 3 , and the measures of our performance gaps are presented in Section 4. We test for various explanations for the performance gaps in Section 5 and draw conclusions in Section 6. 


\section{Review of the Literature on the Relative Performance of Male and Female Entrepreneurs ${ }^{1}$}

In this section we briefly review the literature that evaluates the relative performance of male and female-owned firms by summarizing what we know about the types and sizes of gender gaps in entrepreneurial performance (Section 2.1) and what explanations have been offered for the gaps that have been found (Sections 2. 2). This literature spans a wide array of disciplines and journals. Since we focus on firm performance, we do not, for example, cover the vast labor economics literature on 'selfemployment' as a proxy for entrepreneurship. Most studies of women business owners are in managerial journals; they tend to be descriptive and based on small sample sizes in one country (see e.g., Brush, 1992 for a review). Our analysis is more rigorous, based on economic theory of the firm, and uses a large firm-level data set for numerous countries.

\subsection{Measures of Relative Performance}

The evidence on the effect of gender on firm performance is mixed. Some studies provide evidence of female underperformance (e.g., Brush, 1992; Rosa et al., 1996), while others do not find gender-based differentials (e.g., Du Rietz and Henrekson, 2000; Bardasi, 2007). The findings depend in part on which measure of performance is used and what other factors are being controlled for.

A growing body of evidence consistently shows that female-owned enterprises are smaller -- in terms of sales, assets and employment -- than male-owned enterprises (Chagnati and Parsuraman, 1996; Coleman, 2007; Robb, 2002; Watson, 2002, Loscocco and Robinson, 1991). For example, Coleman (2007) finds that - as recently as 1998 in the US - among small firms (fewer than 500 employees), the average male-owned business was twice as large as the average female-owned business in terms of total sales and assets and had 50\% more employees (without holding anything else constant). Similarly, Chagnati and Parsuraman (1996) find (using US data) that sales are twice as large in male-owned business as in female-owned business. However their sample (less than 400 firms) was much smaller than Coleman's sample of 2,800 firms and covered smaller firms (4 - 99 employees). While these two studies only provide only 'unconditional

\footnotetext{
${ }^{1}$ This section was enriched tremendously by the chapter on 'Female Entrepreneurship' in the forthcoming new edition of Simon Parker's textbook Economics of Entrepreneurship. We are grateful to him for sharing it with us.
} 
means,' Loscocco and Robinson (1991) find sales lower for women among small business owners in same industry comparisons (equivalent to the 4-digit ISIC) in the US. Their conclusions are drawn from comparing mean sales in industrial sub categories dominated by women compared to the sales in categories dominated by men. There findings are reminiscent of the occupational segregation or occupational crowding literature (e.g., Meng and Miller, 2001, Preston, 1999).

Some studies also indicate that firms owned by women are less profitable than those owned by men. Robb and Wolken (2002) study a sample of white-owned small businesses in the U.S. and show that women owned businesses generate only $78 \%$ of the profits generated by male-owned businesses. Bosma et al. (2004) find male Dutch business owners outperformed women in terms of profit. Neither of these studies conditions on the industrial location of the firm.

Other studies, however, do not find females perform less well when other measures of performance (such as return on equity, total factor productivity, growth of sales or employment) are used. In a study from Australia, Watson (2002) shows that women business owners earn similar rates of return on equity and assets as male business owners. Using World Bank Enterprise Surveys (2002-2006), Bardasi et al. (2007) find that in Africa, female-owned businesses are at least as productive as male entrepreneurs when measured by value added per worker and total factor productivity, holding constant the industry in which they work. Similarly, Kepler and Shane (2007) show that there are no significant gender differences in terms of performance outcomes of nascent entrepreneurs.

The research findings with respect to gender differences in the growth of the business are mixed. Some studies show that female-owned enterprises do not underperform in terms of employment growth (Fischer et al., 1993; Chagnati and Parsuraman, 1996) whereas others do (Bosma et al., 2004). Some find that women-owned firms have significantly higher annual sales growth than men (Coleman, 2007).

\subsection{Explanations for Differences in Performance}

In studies where gender differences in firm performance emerge, various explanations for these differences are proposed ranging from psychological and social differences between male and female entrepreneurs to institutional constraints. We focus 
here on the two which we will address in our analysis - women's selection into various sectors and institutional constraints.

\section{Gender composition of industries}

One explanation for the lower performance of female entrepreneurs is that they are disproportionately concentrated in certain industries, which have characteristics that explain their performance (e.g., the less well performing industries or in more competitive industries where there are lower profits). Systematic gender differences in overall industry composition have been documented in the US and elsewhere. Women entrepreneurs are seen to be heavily concentrated in retail sales and services (Bates, 1995; Kallegerg and Leicht, 1991; Du Rietz and Herekson, 2000; Loscocco and Robinson, 1991; Verheul et al., 2004) while industries like construction remain heavily dominated by men (Bates, 1995; Loscocco and Robinson, 1991). Moreover, it has been shown that women are less likely than men to operate business in high-technology sectors in the US (Loscocco and Robinson, 1991; Anna et al., 1999). Mayoux (1995) claims that: "Women are overwhelmingly clustered in a narrow range of low investment, low profit activities for the local market.” Loscocco and Robinson (1991) show that women are concentrated in sectors which tend to have lower sales revenue on average. Hundley (2001) shows that industrial choice explains about 9 to 14 percent of the gender based self-employment earnings differential. This was largely due to the concentration of women in personal services sector and their under-representation in the more lucrative professional services and construction industries.

\section{$\underline{\text { Institutional Factors }}$}

Barriers to female entrepreneurship can arise from existing institutional structures, both formal and informal. Welter and Smallbone (2003) argue that while formal institutions can influence opportunities for entrepreneurship, informal institutions can strongly affect perceptions of entrepreneurial opportunities. This is particularly relevant in the context of female entrepreneurship. Aidis et al. (2007) catalogue the important institutional influences on female entrepreneurship. With regard to formal institutions they identify formal gender equality recognized by law, labor market legislation, tax legislation and child care infrastructure as being important. In the context of informal institutions discrimination against women in the workplace, traditional attitudes, religious 
beliefs, perception of entrepreneurship as a male activity, social attitudes towards women and employment and family values are highlighted as important institutional influences on female entrepreneurship. We focus on institutional factors that may affect access to capital.

First we note that the literature tends to find that women have less access to capital. For example, in a study from Australia, Watson (2002) shows that women business owners have less start up capital, which explains their lower incomes and profits compared to men. Coleman (2007) found that among small business owners in the US, women were less likely to have a loan of any type ( $46.5 \%$ v. $58.9 \%$ of the men) and a significantly lower percentage had loans from banks ( $27.3 \%$ v. $39.3 \%)$. Similarly women were significantly less likely to have a line of credit (18.8\% v. 32.2\%). Finally Carter and Rosa (1998) estimated that in Britain, the average female entrepreneur uses a third less external finance than the average male entrepreneur.

Is differential access to finance due to discrimination? Several studies suggest that raising capital is more difficult for women than men in the US (Brush, 1992: Carter and Cannon, 1992: Carter 2000) and Eastern Europe (Muraveyev et al., 2007), but it is not clear whether it is due to discrimination on the part of the banking sector or the result of other factors.

Some studies infer that discrimination by banks can be a factor. An interesting study by Fay and Williams (1993) tested for discrimination by sending out identical loan applications, whose sole difference was the gender of the hypothetical applicant. They found that the applications were significantly more likely to be declined or restricted if the name was that of a woman than a man. In their study using data from Business Environment and Enterprise Performance Survey (BEEPS) from Europe, Muravyev et al. (2007) find that female managed firms have a 5.4 percent lower probability of securing a bank loan than male managed firms. They also evaluate existence of financial constraints by looking at interest rates and find that female managed firms on average pay 0.6 percent higher interest rates than their male counterparts. Both these factors suggest discrimination against female entrepreneurs and the authors suggest that this discrimination is found to be higher in the least financially developed countries in the region. This is corroborated by Aidis et al. (2007), who - using original survey data from 
Lithuania and Ukraine - show that access to funds is a more important barrier for female business owners than their male counterparts. In survey data from Ukraine, women were more likely than men to cite financial constraints as an important obstacle to running their business. These financial constraints also included greater under-capitalization at start up and less ability to raise external funds.

There is some evidence against the discrimination story in the US and Canada. In studies with larger sample size than that of Fay and Williams (1993), only modest or negligible differences were found in the way that bank loan officers perceived gender in business loan applications (Buttner and Rosen, 1989; Wilson et al., 2007). Similarly, the terms of loans grated to male and female business owners did not vary significantly in a Canadian national study (Riding and Swift, 1990). Once one controls for the size and age of the venture and the particular industry, gender differences in access to and terms of finance (including rates of loan approvals and collateral requirements) tend to disappear (Coleman, 2000; Orser et al., 2006). Using data from the Survey of Small Business Finances in US, Cavalluzzo and Wolken (1998) find that after controlling for personal wealth (in the form of home ownership, home equity, personal net worth etc.), differences in denial rates between male and female-owned firms are not statistically significant. Similarly, in a study on micro and small enterprises in Trinidad and Tobago, Storey (2004) tests for the presence of racial and gender discrimination in bank loans. They take the reported refusal to grant loans to groups, when all other indicators of credit-worthiness are taken into account, as evidence of discrimination and find neither application nor denial rates differ significantly by gender once all other indicators of credit-worthiness are taken into account.

If discrimination does not explain loan decisions, why does the average female entrepreneur start business with less capital or have less access to bank finance than men? Significant differences in male and female access to finance may be accounted for by differences in other characteristics affecting their credit worthiness including human capital factors and personal wealth. For instance, women may have on average more difficulties in securing a loan than men because they concentrate in the sectors such as services, which need less capital (Verheul and Thurik, 2001). Since banks typically lend on the basis of "hard assets" such as plant and equipment, of which service businesses 
have few, they are less likely to obtain a loan. Another argument is that they tend to run business in sectors with fewer market growth opportunities so it may be optimal for both lenders and entrepreneurs (Oser et al., 2006).

If women entrepreneurs are less growth oriented or run firms at lower capacity, this might also explain the lower supply of finance from the bank perspective. Several studies using US and UK data have found that women entrepreneurs are more likely than men to be working part-time. This is shown with data on both self-employed individuals (Devine, 1999a, 1999b) and firms (Loscocco and Robinson, 1991). For example, Census data collected in 1982 show that while 60\% of women owners worked fewer than 29 hours per week, only 41 \% of their male counterparts did so. Loscocco and Robinson (1991) report that only $27 \%$ of the women in their sample of small business devoted over 40 hours per week to business compared to $48 \%$ of the men.

However, is the lower access to loans explained by demand side behavior, such as lower applications to banks by women because they are more risk averse or for other reasons? Some papers show that women tend to have higher risk aversion (Jianakopolos and Bernasek 1998, Barber and Oden 2001, Dohmen et al 2005). These differences could have important implications for business performance if higher risk aversion leads women to restrict investment in their business ventures. The Global Entrepreneurship Report 2005 found that fear of failure is significantly higher for women than men in middle income countries (Minniti et al 2005). In addition, Kepler and Shane (2007) claim that male nascent entrepreneurs examine more ideas and gather more information while pursuing a new start-up than female nascent entrepreneurs. Do women use less external

finance and depend more on own reinvesting own profits? There is some evidence to suggest that men re-invest a larger share of profits generated back into their business (Grasmuck and Espinal, 2000). See also Kim (2006) for US; Carter and Rosa (1998) for similar evidence in the UK.

\section{Data}

In this paper we use the 2005 Business Environment and Enterprise Performance Survey (BEEPS) data, produced by the World Bank and the European Bank for Reconstruction and Development (EBRD). This dataset provides detailed firm level data for 26 post-socialist economies: 15 from Central and Eastern Europe (CEE) and 11 from 
the Commonwealth of Independent States (CIS). ${ }^{2}$ The original 2005 database is comprised of about 9,500 firms, with 200-600 firms per country. The sample was constructed by stratified random sampling from a national registry of firms. In each country, the sectoral composition of the sample in terms of manufacturing versus services was determined by their relative contribution to GDP. Firms that operate in sectors subject to government price regulation and prudential supervision, such as banking, electric power, rail transport, and water and waste water, were excluded from the sample. The sample includes only registered firms (i.e., not informal firms), and their size varies from as few as 2 employees to as many as 9,999 employees. Moreover, firms in rural areas and small towns are represented since at least $10 \%$ of firms in the sample are in a small city or the countryside (i.e., population under 50,000 inhabitants).

The data enable us to identify the gender of the largest shareholder (owner) of individually or family owned firms. Hence in this paper we define male v. female entrepreneurs as "male v. female sole or principal owner of individual or family owned firms.” ${ }^{3}$ These individuals are also the main managers of the firm. Other strengths of these data from our perspective include the fact that the same survey instrument was administered in 26 countries in the same year; that there are a host of performance variables for each firm; and there are a set of questions dealing with institutional factors, especially in the area of finance, which may affect the relative performance of male and female-owned business. The weaknesses include a) the small number of firms sampled in each country; b) inability to identify the gender of the other owners of the firm when there is more than one; c) lack of demographic information on the entrepreneurs; and d) the numerous missing answers to some variables of interest (e.g., capital).

\footnotetext{
${ }^{2}$ The 15 CEE countries are: Albania, Bosnia and Herzegovina, Bulgaria, Croatia, Czech Republic, Estonia, Former Yugoslavia, FYROM, Hungary, Latvia, Lithuania, Poland, Romania, Slovak Republic, and Slovenia. The 10 CIS countries are: Armenia, Belarus, Georgia, Kazakhstan, Kyrgyzstan, Moldova, Russia, Tajikistan, Ukraine and Uzbekistan. Note that Turkmenistan never entered the BEEPS sample.

${ }^{3}$ These are existing firms, rather than "nascent" firms. To the extent that there are gender differences in the survival of firms, we may have a biased sample. However, given Kallebert and Leicht (1991) and Ruderl and Preisendorver (1998) have found no significant differences between the survival rates of male- and female-owned businesses, our sample should not be biased on this dimension. If survival bias is stronger among women, then our results comparing existing firms owned by men v. women might be upwardly biased for all women entrepreneurs.
} 
There are about 7,000 firms where the largest shareholder is an individual or family; ${ }^{4}$ however, as Table 1 shows, a number of firms are missing observation for the performance measures. Hence, our analytical sample is restricted to approximately 3,334 firms once we delete observations: a) with missing information on capital (since only 3,531 firms have information on fixed assets or capital) or sales or labor, and b) from two-digit NACE industries with fewer than five firms. The result is that the analytical sample does have somewhat higher mean sales, cost of material inputs and profits than the original sample.

We begin with three basic descriptive statistics of female-owned firms in ECA. First the higher concentration of males in business ownership is evident in this region as in most of the world. In 2004, $26.8 \%$ of all entrepreneurs were women. This share is slightly lower to that found in the global averages, where according to Reynolds et al. (2002), men are about twice more likely to be involved in entrepreneurial activity than women. However, the average in our data is higher than that found in the 2005 GEM data base for "nascent entrepreneurs" in 35 countries. There the rates of female entrepreneurship range from about $1-2 \%$ in Netherlands and Japan to nearly $20-24 \%$ in Venezuela and Thailand (Minniti et al., 2005). The country level shares of female entrepreneurs in our data, shown in Figure 1, range from above $40 \%$ in Latvia to below $15 \%$ in Armenia. Explanations for the variance in the share of female entrepreneurs across countries are left for another paper, which can exploit panel data on countries over time. However, we provide a simple plot in Table A4, which indicates a positive association between the level of female education (share with secondary level schooling in a country) and the share of female entrepreneurship.

Second, again as found in other parts of the world, women in this region own significantly smaller firms than men, when measured by the number of permanent employees. About 57\% of all female-owned enterprises employ fewer than 10 permanent employees in contrast with $41 \%$ of male-owned enterprises (see Figure 2). This finding is addressed in greater detail below.

\footnotetext{
${ }^{4}$ We have therefore excluded from the analysis firms where the largest shareholder is the state, domestic and foreign companies, banks, or employees or management.
} 
Third, we find that women business owners are more likely to be in certain industries than others: about $22 \%$ of all female entrepreneurs are found in retail and wholesale trade and $14 \%$ in textiles and apparel, while only $6 \%$ are in construction and less than $1 \%$ are in extraction activities (mining). Hence, not surprisingly a large share (45\%) of the entrepreneurs in textiles and apparel are women, while in mining only $8 \%$ of the entrepreneurs are women.

\section{Performance Gaps}

In this section we first measure performance gaps in various ways: in terms of profits, firm size (total sales), and efficiency (profits controlling for output and TFP). We then perform a robustness test of our TFP measure using propensity score matching techniques (Section 4.2). In Section 4.3 we ask whether the scale of operation of male and female entrepreneurs is suboptimal. We first present results for all 26 ECA countries in our sample (Table 2a) and then present results for European Union (EU) member countries and non-member countries (Non-EU) separately (Table 2b). ${ }^{5}$

\subsection{Differences in Firm Size and Efficiency}

The unconditional (raw) average profit is 227 Euros in a male-owned firm and 166 Euro in a female-owned firm in ECA in 2004. Hence, the average female entrepreneur earns 61 Euros less (see appendix Table A1). ${ }^{6}$ When we correct for outliers by using robust regression methodology and take into account the country fixed effects, the gender gap in profits falls to only 11 Euros but this difference remains statistically significant. ${ }^{7}$ Finally, when we control for both industry and country fixed effects in a robust regression, the differences falls from 11 to 7 Euros; it remains statistically significant (see first panel in Table 2a). Hence, the inclusion of industry effects is important; it reduces the gap to only $3 \%$ of average male profits - from $27 \%$ for the unconditional mean gap.

\footnotetext{
${ }^{5}$ EU countries in the sample include: Bulgaria, Czech Rep, Estonia, Hungary, Latvia, Lithuania, Poland, Romania, Slovakia and Slovenia. Non-EU countries in the sample include: Albania, Armenia, Belarus, Bosnia, Croatia, FYROM, Georgia, Kazakhstan, Kyrgyz Rep, Moldova, Russia, Tajikistan, Turkey, Ukraine, Uzbekistan and Yugoslavia.

${ }^{6}$ These gaps in appendix Table A1 are calculated by giving each firm in the sample the same weight. We might consider weighting firms by size of GDP or Population of the country to make them "representative" of the region as a whole. In the original sample more firms were included in the larger countries so they are roughly representative.

${ }^{7}$ These results do not change when we also control for the age and location (capital city v. other) of the firm.
} 
Similarly, sales revenue ${ }^{8}$ of the average female entrepreneur in a given country in ECA is significantly (63.1\%) smaller than that of the average firm owned by a man (using robust regression methods);, once we control for the (two digit) industry in which the firm operates, the difference falls dramatically to $37.2 \%$ (see second panel in Table 2a). Hence, on average sales revenue in a female-owned firm in a given industry and country in ECA is less than two-thirds that of a male-owned firm in that industry.

These findings suggest that women's firms are smaller in terms of sales revenues and profits than men's firms. Once we control for concentration of female entrepreneurs in different industries, the difference in their size and profits falls, but remains significant. We return below to the question "What is it about the industries in which women are located in that drives down these differentials?”

In the third panel of Table 2a we next explore gender gaps in efficiency, using both a measure of financial efficiency and total factor productivity (TFP) We ask whether the profit gap we found above could be brought about by a different scale of operation, hence we estimate the differences in men's and women's profits controlling for sales, which can be seen as a measure of financial efficiency. ${ }^{9}$ We find that by this measure, there are no statistically significant differences between male and female entrepreneurs in ECA. Hence the originally detected lower profit in female-owned firms is accounted for entirely by the lower scale of operation.

Are female entrepreneurs less productive in terms of the revenue that they generate from given inputs than males? The TFP findings are obtained from estimating a Cobb-Douglas production function with pooled firm-level data from all 26 countries: ${ }^{10}$

$$
\ln Y_{i j}=\alpha^{k} \ln K_{i}+\alpha^{L} \ln L_{i}+\alpha^{M} \ln M_{i}+\delta F_{i j}+I \phi+C \eta+\varepsilon_{i j}
$$

where $\ln Y$ is the $\log$ of sales revenues, ${ }^{11} i$ and $j$ index firm and industries (at the two-digit NACE level), respectively. The inputs include: $K$, capital stock (at replacement value); $L$,

\footnotetext{
${ }^{8}$ In the analysis, sales revenue is logged but profits are not logged in order to preserve negative observations for profits.

${ }^{9}$ The financial literature often uses the profit rate (profit/sales) as a measure of efficiency. We also ran this regression with the profit rate on the left hand side and a female dummy on the right hand side and find that there is no significant gender difference in the profit rate. We prefer our specification it allows us to see that differences in profits by gender are brought about by the scale of operation.

${ }^{10}$ Equation (1) can also be interpreted as a first order approximation for more complicated revenue (production) functions.
} 
labor (number of permanent employees) and $M$, intermediate material input (including electricity). $F$ is a dummy variable equal to one for a female entrepreneur; $I$ is a set of industry fixed effects and $\mathrm{C}$ is a set of country fixed effects.

The estimated $\delta$ coefficient on F, presented in the next-to-last column of Table 2a, indicates that the average female-owned firm is only slightly (2.1\%) less efficient than the average male-owned firm in a given industry. ${ }^{12}$ It is argued that women's lower TFP is driven by lower capacity utilization. In the last column of Table 2a we estimate differences in TFP after adjusting capital for capacity utilization and find that this does not change the result. Figure 5 shows the kernel density distributions of the TFP of male and female entrepreneurs. Comparing the two we find that they are highly overlapping, indicating little difference in total factor productivity by gender of the entrepreneur.

If differences in the institutional environment of countries matter, it is possible that within the ECA region, there are differences between the EU and Non-EU countries in the relative performance of male- and female-owned firms. Hence in Table $2 b$ we replicate the regressions of Table 2a for each set of countries. We find similar patterns between the two groups of countries for all performance indicators except TFP. That is, for both EU and Non-EU countries gender based gaps exist in log sales and profits and diminish once we control for industry fixed effects. There is no evidence of gender differences in financial efficiency in either EU or Non-EU countries. However, gender based differences in TFP are statistically significant only in Non-EU countries, not in their EU counterparts.

Hence we conclude that on average female-owned firms in the ECA region are slightly less efficient in terms of total factor productivity but equally efficient in terms of financial efficiency (profits controlling for firm size and industry). The gender difference in TFP in the region is being driven by differences in the Non-EU countries.

\footnotetext{
${ }^{11}$ Strictly speaking TFP is estimated with output. However, this is rarely implemented, except in studies of a single industry with a homogeneous product (such as cement). Most studies use revenue as we do and control for price differences with a price deflator. Since this not available, we use industry fixed effects to control for price (and other) differences across industries.

${ }^{12}$ We find that estimating this equation as an industry specific production function (i.e., interacting the inputs with two-digit industry dummies) does not affect the coefficient on the female dummy. With this specification, the coefficient is estimated as -0.028 , with a standard error of 0.009 .
} 


\subsection{Robustness Check of Differences in Efficiency (TFP)}

The issue of concentration of women entrepreneurs in certain industrial categories and smaller firm size, which has received some attention in the literature, is confirmed in the ECA region. Moreover, since on average female entrepreneurs constitute merely 27 percent of all entrepreneurs in this region, one need question whether there might not be several industrial categories where males are present but female entrepreneurs are entirely absent. In this situation a comparison of male and female entrepreneurial performance using traditional regression analysis would compare productivity of male entrepreneurs by projecting productivity of female entrepreneurs in industry and size categories where they are in negligible numbers or nonexistent. Hence it becomes important to ensure that in making firm productivity comparisons we do not consider firms in those industry or size categories where the productivity of female entrepreneurs is not observed.

We use propensity score matching (PSM) methods as an alternative specification to test the robustness of our regression analysis. Matching methods allow us to weight our dataset in a way that the observations we analyze are more comparable. Male and female entrepreneurs are matched on industry (disaggregated at the two digit ISIC code level) and level of input use (labor, capital and materials). Average treatment effects are then calculated for lnSales. This method allows us to compare the sales of male and female entrepreneurs that are in similar industries and on similar scales of production, thereby allowing us to obtain the average effect of being a female entrepreneur on TFP. Propensity scores are calculated by using a logit regression in which dummy for female ownership is used as the dependent variable and log of inputs (labor, capital and material), industry and country dummies are used as independent variable.

A necessary condition for the implementation of PSM methods is a sufficiently large overlap in the distribution of observable characteristics between control (male entrepreneurs) and treatment groups (female entrepreneurs). This condition is known as ‘the common support condition'. On controlling for industry and inputs we obtain a large common support area. Only two observations from the treatment group are dropped due to lack of similar control group observations. For comparison we have 2332 observations for our control group of male entrepreneurs and 858 observations for the treatment group 
of female entrepreneurs. To obtain average effects of being female we implement 'Nearest Neighbor Matching,' both with and without replacement.

The results from the PSM method, presented in Table 3, indicate that if we use the stricter method of "matching with replacement," we find there is significant difference (at the $5 \%$ level) of 0.15 between the mean lnTFP of males and females. In percentage terms the gap is $-2.7 \%$, which is quite similar to the significant gap estimated in the regression of $-2.5 \%$ (in Table 2). If we use the less stringent method of "matching without replacement," the gender gap in TFP (of $-4.1 \%$ ) is significant at the $5 \%$ confidence level and larger than the gap estimated using the regression technique. Since the findings with the regression method are close to those using the more stringent PSM estimate, we conclude that they are robust. Although the difference in TFP is statistically significant, it does not appear to be large in terms of its economic significance.

The next question is whether the differences in TFP are related to the differences in scale. In particular, since women's firms are smaller than men's, are they inefficiently small?

\subsection{Are Women's Firms Operating at a Suboptimal Scale?}

In order to determine the extent to which the scale of operation of male and female-owned firms are different and suboptimal, we test for returns to scale in the framework of the production function. We estimate equation (1) separately for men and women using a robust variance method and clustering the standard errors by two-digit industry. We perform two-tailed Wald tests to learn if men's returns to scale are constant (i.e., Ho: $\alpha_{k}+\alpha_{l}+\alpha_{m}=1$ ) and, similarly, if women's returns to scale are constant (Ho: $\left.\beta_{\mathrm{k}}+\beta_{\mathrm{l}}+\beta_{\mathrm{m}}=1\right)$. We then test for increasing returns to scale, using a one-tailed Wald test. We reject the hypotheses of constant returns to scale and cannot reject the hypothesis that men's and women's returns to scale are increasing (1.024 for men and 1.049 for women). We then compare the set of coefficients for men and women and find that we cannot reject the hypothesis that women's returns to scale are higher than those of men (see Table 4a and 4b). 
We also explore differences in returns to scale by industry type, where industries are classified as being in manufacturing or services. ${ }^{13}$ On performing Wald tests similar to the ones described above, we find that returns to scale are greater than one for male and female entrepreneurs in both manufacturing and service industries and the returns to scale for female entrepreneurs are higher than those for male entrepreneurs within manufacturing and within service industries (see Table A1).

Hence, we conclude that both male and female entrepreneurs are operating at an inefficiently small scale (in the zone of increasing returns), and that women's firms do so to a greater extent than men's. We note, however, that the difference from constant returns is quite small as is the difference between men and women.

These differences in returns to scale persist when we decompose our sample by EU membership (Table 4b). Returns to scale are greater than one for both men and women in EU and Non-EU countries. It is interesting to note that returns to scale are slightly higher for both men and women in EU countries compared to their Non-EU counterparts. These results might reflect structural differences in the business environment among these countries and merit further investigation. In both the samples we find that returns to scale for female entrepreneurs are significantly higher than male entrepreneurs.

\section{What Explains Why Women Are Operating Smaller Businesses?}

We have found that women are operating smaller businesses than men and they are somewhat less efficient both in terms of total factor productivity and in terms of optimal size. We noted that holding industry constant reduces the gap in size and hence ask "What is it about the characteristics of the industry that women are located in that explains these gaps?” However, since a gap remains even within each industry, we also ask whether women are being constrained to be small by some institutional factors in the credit market.

\footnotetext{
${ }^{13}$ Manufacturing industries include extraction, food \& tobacco, textiles \& apparel, wood \& paper products, chemicals, basic metals, construction and other manufacturing. Service industries include wholesale \& retail trade, maintenance \& repair, hotels \& restaurants, transport, post \& communications, financial services, renting, health, education, recreation and other services.
} 


\subsection{Are Women in "Poorly Performing" Industries?}

The literature hypothesizes and finds some evidence that the poorer performance of female-owned businesses can be attributed to the fact that they are "crowded" in "poor performing” industries. We noted above the study by Mayoux (1995) which claims that "Women are overwhelmingly clustered in a narrow range of low investment, low profit activities for the local market” and the paper by Loscocco and Robinson (1991) which shows that in US women are concentrated in sectors which tend to have lower sales revenue on average. If women are concentrated in industries that inherently use less capital, or only serve the local market or are more competitive, this might explain why they are smaller. This could also potentially explain why they are relatively less efficient (in terms of TFP) than men.

We explore these questions by plotting four average characteristics of an industry (at the two-digit level) against the share of women in that industry, and fitting a regression line to the scatter plot. Although the results in Figure 4 tend to show negative correlations between all these characteristics and the share of women in an industry, these correlations are not significant in three out of the four plots. I.e. there is no evidence that women tend to be in industries that are less capital intensive (proxied by capital-labor ratios) or more competitive (proxied by the cost-price markup) or have a lower output per worker. However it does appear from the fourth plot in Figure 4 that women entrepreneurs are more likely to be concentrated in industries where the average firm's sales are smaller. Hence the fact that women entrepreneurs have smaller firms is in part explained by the product or service they produce (i.e., industry they are located in).

In addition to asking whether women are concentrated in capital or labor intensive activities, it is interesting to know whether women perform as well as men in industries that are capital or labor intensive. To answer this question, we augment the production function in equation (1) with variables for the average level of capital and labor in an industry and interact these two variables with the dummy for female ownership. The results, shown in Table 5, indicate that on average total factor productivity is lower for men who are located in industries with more capital (holding labor constant) but it is even lower for women in these industries. On the other hand, there is no difference in total factor productivity of men and women in more labor intensive industries. 
Finally we ask, to what extent is the variation in sales of male and female-owned businesses attributable to between industry gaps $\mathrm{v}$. within industry gaps. To address this question we use one-way analysis of variance methods. The results, shown in Table 9, indicate that while the variation in sales revenue of male entrepreneurs is highly concentrated within industries (91\% of total variation comes from within industry); for female entrepreneurs this variation comes both from within industry gaps (74\%) and also from between industry gaps (26\%). This suggests that choice of industry has a relatively bigger role in explaining firm size/sales for female entrepreneurs than their male counterparts.

The findings that women i) fare worse in more capital intensive industries, ii) are concentrated in industries with lower average firm sales and iii) are operating at a suboptimal scale lead us to ask whether female-owned firms are being constrained to be small by lack of access to capital.

\subsection{Are Women's Firms Constrained to Be Small?}

Although economically the increasing returns found in Table $4 \mathrm{a}$ and $4 \mathrm{~b}$ are not large, they suggest that over time we should observe the scale of firms increasing in the economies of Central Asia and Eastern Europe. Moreover, if women’s firms are currently more constrained to be inefficiently small than firms owned by men, removing these constraints will result in greater growth of female-owned firms than male-owned firms. In this section we ask to what extent male and female business owners are constrained from reaching their optimal scale by lack of access to capital. We first ask whether or not women are more constrained than men in access to capital and we then test for the relative gender effects of capital constraints on their scale of operation and productive efficiency.

Since another paper answers the first question with the same BEEPS data, we rely on the results of this study. Muravyev, Schafer and Talavera (2007) have shown that women are (5.4\%) less likely than men to get a loan, when correcting for selection on whether the firm needs a loan, and controlling for the profit of the firm, capacity utilization, age, and competition faced by the firm, as well as industry and country fixed effects. They note the importance of controlling for capacity utilization and age; if women are operating firms that are younger and at lower capacity utilization than men 
and this could influence the financial decisions of bankers. They also show evidence that women are charged $0.6 \%$ higher interest rates than men. They conclude that this evidence suggests gender discrimination against female entrepreneurs by financial institutions; which would indicate that women are more capital constrained than men.

To test for the effects of capital constraints on the scale and efficiency of operation, we use four variables. The first variable, Bank Finance is a dummy variable = 1 , if the firm has financed part of their working or investment capital from a bank in the past year. The second constraint variable is a subjective measure that assesses whether "access to financing is an obstacle to the operation and growth of the business." We code Access to Finance as a dummy variable $=1$ if it is considered an obstacle and 0 otherwise. The third variable we use divides firms into those "which need a loan but did not get one or did not apply for one because they felt interest rates were too high, etc.” (Need Loan = 1; 0 otherwise); those which "did not need a loan and did not apply for one" (Did not Need Loan = 1; 0 otherwise) and firms that received a loan from the bank (Received Loan = 1; 0 otherwise). The fourth variable is simply the interest rate on the loans (proxying the cost of capital) which is only observed for the sub-sample that obtained a loan.

As seen in appendix Table A2, the means of these variables indicate that on average men and women are equally (and very) likely to view access to finance as a constraint. Women are significantly less likely to receive a loan (37 \% v. $43 \%$ of men) and significantly more likely to not get one if they need it (25\% v. $19 \%$ for men) although equally likely to say they do not need a loan (about 25\%). Women and men are equally likely to receive financing from a bank for working or investment capital (about half do). On average, there is no difference in the interest rate that male and female entrepreneurs pay; on the other hand, average value of collateral for male entrepreneurs is significantly lower than that of female entrepreneurs. Muravyev, Schafer and Talavera (2007) show that once controls are introduced, there is a significant difference in the interest rate paid by men v. women.

Firms rely on sources other than banks for funding. Appendix Table A3 indicates that internal funds/retained earnings accounts for the largest share of financing of working capital (67.8\% for men and 71.7\% for women) and investment (64.3\% v. 68.5\%) 
and that women tend to rely on this source more than men. Borrowing from banks is the second largest source of financing for both men and women however it accounts for a higher share for men: i.e., $12.6 \%$ of working capital and $17.1 \%$ of investment capital for men v. $8.9 \%$ and $12.7 \%$ respectively for women. Reliance on equity financing does not differ by gender and is relatively small, which is not surprising given the lack of development of stock markets in these countries as of 2004. Borrowing from informal sources (e.g., family, friends and money lenders) is not very substantive and it does not appear to be larger for women than men. Trade credit from suppliers or customers is of course more important for working capital (especially for women) while leasing arrangements are more important for new investment (especially for men). Hence internal financing and bank financing appear to be the two most important sources of financing; it also appears that women rely more on the internal financing and less on banks compared to men, which is consistent with the literature (e.g., Coleman, 2007; Carter and Rosa, 1998).

To test whether business owners with less access to capital have a smaller scale of operation, we regress sequentially the three measures of capital constraints, as well as the cost of capital (the interest rate), on log sales of the firm; we also ask whether these factors affect men and women in the same way by interacting the female-owned dummy with each of these variables. To avoid the problem of reverse causality, given that firms with larger sales might be more likely to obtain financing from banks, we control for lagged sales (sales in 2002) in these regressions. The results from the regressions presented in Table 6a generally show that, after controlling for sales three years earlier, firms with better access to capital in the previous year generate somewhat higher sales revenue. There is no significant difference between men and women in the effect of capital constraint on sales. Specifically, both female and male-owned firms that received at least part of their working or investment capital from a bank in the past year (Bank Finance) have $1.5 \%$ higher sales than those who do not receive financing from a bank (column 2) and similarly firms that received a loan from the bank (Received Loan) have sales that are $1.7 \%$ higher than unconstrained firms, which did not need a loan and did not apply for one (column 3). On the other hand, while male-owned firms that complain more about access to finance being a constraint to business operation do not fare 
significantly worse than firms that do not complain, the opposite is true for women: women-owned firms who complain about being capital constrained have larger sales revenue than firms that do not complain. This result is harder to interpret given that we do not have much information on how subjective perceptions regarding access to finance are formed. Finally, the results for the cost of capital indicate that firms which pay a higher interest rate generate similar sales revenue as firms which pay a lower interest rate, whether owned by a man or a woman (column 4). However, the rate of interest can be affected by the level of collateral a firm puts up. In column 5 we show that even when the value of collateral is held constant the results discussed above persist.

Table $6 \mathrm{~b}$ presents results for the access-to-capital regressions estimated separately by EU and Non-EU membership. Most importantly, we find that bank finance has a significantly positive impact on firm sales in EU countries but not in Non-EU countries with both of our measures (columns 1, 2 and 5, 6). Further, according to one measure female entrepreneurs who have access to bank finance perform better than their male counterparts in Non-EU countries but not as well as their male counterparts in EU countries. However, this result is not robust with the second measure (have a loan), which shows no significant difference between male and female entrepreneurs. These results suggest that the environment surrounding access to bank finance may differ in these two groups of countries and this has a discernable impact on the way this finance affects firm performance. The reasons behind these differences need to be explored and could have important policy implications for the ECA region.

To what extent is productive efficiency (TFP) of male and female entrepreneurs affected by capital constraints? We find that entrepreneurs that have bank financing have significantly higher TFP; there is no difference between male and female entrepreneurs. However, the other capital constraint variables do not show any significant effect on TFP, although the signs seem to move in the expected direction. Nor does TFP vary with the cost of loans (see Table 7).

Next we ask whether together with the smaller scale, female entrepreneurs use the same or different capital intensity in production as male entrepreneurs. The small scale may be brought about by K constraints. We ask here: Do male and female entrepreneurs use different $\mathrm{K}: \mathrm{L}$ ratios, and, if so, is the use of $\mathrm{K}$ and $\mathrm{L}$ affected by constraints and/or 
input prices they face? We regress $\ln (\mathrm{K} / \mathrm{L})$ at the firm level on the female-owned dummy, the lnSales of the firm, and then add the capital constraint and cost variables sequentially. The estimated coefficients on the female-owned dummy in Table 8 suggest that the average capital labor ratios of male and female entrepreneurs do not differ significantly, within an industry and country (column 1) or when the size of firm is held constant (column 2). The capital-labor ratios fall with an increase in sales revenues and this relationship does not differ for men and women (column 2). This suggests that the firms do not have homothetic production technology or that the relative price of capital to the price of labor rises with the scale of operation (sales). Next we find that firms with access to bank financing, and which have received a loan, tend to use more capital per unit of labor; this relationship does not differ by gender. The coefficient on the interest rate is negative but not significant for men and positive and not significant for women. Taking the results in the table together, it appears that the K:L ratio is more sensitive to access to capital than to its price.

\section{Conclusions}

Using firm level data from the 2005 BEEP Survey of 26 countries in the Eastern European and Central Asian (ECA) region, we explore various questions regarding differences in firm performance of male and female entrepreneurs and test various hypotheses offered to explain the observed patterns.

Our first finding is that there is a significant gender gap in the scale of operations, as measured by sales revenues. This finding is consistent with the literature from individual country studies which show that female business owners (entrepreneurs) run smaller businesses (measured in various ways, including sales and number of employees). Our finding holds even when controlling for the industry in which the firm operates, although the gap falls from being 63\% (when controlling for country fixed effects) to $37 \%$ (when controlling for both country and industry fixed effects).

However, counter to studies which have found large gender gaps in profits (Robb and Wolken, 2002 for the US and Bosma et al., 2004 for Holland), we find that the unconditional average gender gap in profits in the ECA region is small to begin with and falls to $3 \%$ of men's profits after controlling for country and industry. Moreover, we find that the gap vanishes when we control for the scale of the firm (sales) in addition to 
country and industry. Hence women entrepreneurs generate the same amount of profit per unit of revenue as men in ECA.

We provide robust evidence (using two specifications of the production function and applying propensity score matching techniques) that the performance of femaleowned firms in terms of total factor productivity is significantly smaller than that of men in the same two-digit level industry. We note, however, that the average gap, at $-2.1 \%$, is small and may not be economically significant. We also note that since we are using sales revenue rather than output as the dependent variable, the lower TFP of women may be brought about by women facing lower prices than men in the same industries either because of quality or because of comparatively less expenditure on advertising. ${ }^{14}$

On examining returns to scale we find that both men and women are operating in the zone of increasing returns to scale and are therefore inefficiently small. However, we find that women's returns to scale are significantly larger than men's implying that they would gain more in profits for increasing their scale. It must be stressed, however, that neither women nor men are very far from constant returns to scale, even in the service industries where women's returns to scale is highest (1.084).

We then ask why it is that women are operating at an inefficiently small scale. On this question we explore two alternate hypotheses: a) women's firms are small because they are concentrated in industries which have small firms (low sales), or high competition or low capital intensity; b) women are inefficiently small because they are capital constrained. With respect to a), we find evidence that the share of women in an industry is negatively correlated with the industry's average sales per firm but no evidence of a higher concentration of women in industries with lower $\mathrm{K}: \mathrm{L}$ ratios or higher levels of competition. Hence, women do seem to locate in industries with smaller firms.

We also test whether the lower total factor productivity of women is due in part to the industry characteristics. We find that women do indeed fare worse than men in capital intensive industries, whereas they are equally efficient in labor intensive industries. These two findings lead us to explore further the second explanation (that they are capital constrained) for why women’s businesses are small.

\footnotetext{
${ }^{14}$ Indeed we see that women are on average spending a lower share of their sales revenue on advertising.
} 
We find fairly convincing evidence from the Muravyev, Schafer and Talavera (2007) that women in this region (and data set) are less likely than men to get financing from a bank, and they pay higher interests rates when they do. We also find that women who need a loan are less likely to get a loan than men who need a loan. Our analysis also shows that firms that do have access to capital are larger in scale. Hence, we conclude that women in ECA are capital constrained.

To what extent does the capital constraint affect their scale of operations? We show that female firms that are constrained in terms of capital are operating at higher returns to scale than female firms that are unconstrained in terms of capital. Hence, if the capital constraint were lifted they should grow to a more profitable scale. We also find that even though they are capital constrained, women tend to use capital and labor in the same proportions (similar K/L) as men. Hence, we surmise that in response to the constraint on capital, women adjust their scale rather than their factor proportions. Similarly, we found very little effect of access to finance on total factor productivity of either male or female-owned firms. We conclude that access to capital can partially explain the smaller scale but does not seem to affect the efficiency. Firms are adjusting their input to reflect the constraint, which perhaps could be attributed to their managerial skills, technological differences, regulatory environment (e.g., flexibility of labor market enables them to lay off workers easily), which would be useful areas to research in the future.

A separate exploratory analysis of firms in the EU and Non-EU member countries indicates that the patterns found for the entire ECA are similar in some respects and not others. Whereas the overall finding of gender differences in scale and profits is the same, we find that the gender gap in TFP is significant only in the Non-EU countries and not in the EU countries. We do find that women and men are operating at inefficiently small scale in both sets of countries but there is some evidence that women in Non-EU countries fare better than men with access to finance.

There is a stream in the literature that argues that women choose to run smaller businesses because they have limited time outside of home production (see e.g., Dolton and Makepeace, 1986). However, we find women do increase their scale if given more access to capital and they do so at the same rate as men in the ECA region as a whole. 
We also find that significant gender gaps exist only in scale of firm operation and not as some others have argued in firm profitability or efficiency. This further supports the argument that on lifting existing capital constraints they are likely to expand at least as much as their male counterparts.

This paper strongly indicates that further research is needed to explain differences in firm performance between EU and Non-EU countries. Also, there is evidence to suggest that policy in ECA needs to be geared towards easing capital constraints for female entrepreneurs and shifting their concentration to industries with greater growth potential. 


\section{References}

Aidis, R., F. Welter, and Smallbone D. and N. Isakova. 2007. Female entrepreneurship in transition economies: The case of Lithuania and Ukraine. Feminist Economics 13, no. 2:157-183.

Barber, B.M. and T. Odean. 2001. Boys will be boys: Gender, overconfidence and common stock investment. The Quarterly Journal of Economics 116, no. 1:261-292.

Bardasi, Elena and Abay Getahun. 2008. Unlocking the Power of Women. Chapter prepared for the Ethiopia ICA. Toward the Competitive Frontier: Strategies for Improving Ethiopia’s Investment Climate. World Bank, Washington D.C.

Bates, T. 1995. Self-Employment Entry Across Industry Groups. Journal of Business Venturing 10, 143-156.

Blanchflower, D. G., and P.B. Levine and D.J. Zimmerman. 2003. Discrimination in the Small-Business Credit Market. Review of Economics and Statistics 85, no. 4:930943.

Bosma, N., Mirjam van Praag, R. Thurik and Gerrit de Vit. 2004. The Value of Human and Social Capital Investments for the Business Performance of Startups. Small Business Economics 23, 227-236.

Brush, C. G. 1992. Research on Women Business Owners: Past Trends: A New Perspective and Future Directions. Entrepreneurship, Theory \& Practice Summer, 530.

Buttner, E. H and B. Rosen. 1989. Funding new Business Ventures: Are decision makers biased against women entrepreneurs? Journal of Business Venturing 4, no. 4: 249261.

Carter, S. 2000. Gender and Enterprise. In Enterprise and Small Business: Principles, Practice and Policy, edited by S. Carter. and D. Jones-Evans. Harlow: Prentice Hall/Pearson Education Limited.

Carter, S. and T. Cannon. 1992. Women as Entrepreneurs. London: Academic Press.

Carter, S. and P. Rosa 1998. The Financing of Male and Female-owned Businesses. Entrepreneurship and Regional Development 10, no.3: 225-241.

Cavalluzo, K.S. and J.D. Wolken. 2005. Small Business Loan Turndowns, Personal Wealth and Discrimination. Journal of Business 78, no. 6:2153-2177. 
Cavalluzo, K.S. and L.C. Cavalluzo. 1998. Market Structure and Discrimination: The Case of Small Businesses. Journal of Money, Credit and Banking 30, no. 4:771-792.

Chagnati, R. and S. Parasuraman. 1996. A Study of the Impacts of Gender on Business Performance and Management Patterns in Small Businesses. Entrepreneurship, Theory \& Practice Winter, 73-75.

Coleman, S. 2007. The Role of Human and Financial Capital in the Profitability and Growth of Women-Owned Small Firms. Journal of Small Business Management 45, no. 3:303-319.

Committee on Small Business. 1984. Women entrepreneurs: Their success and problems. Washington, D.C.: GPO.

Devine, T. J. 1994. Changes in the wage-and-salary returns to skill and the recent rise in female self-employment. American Economic Review 84, 108-113.

Dohmen T.F. A., D. Huffman, U. Sunde, J Schupp and C.G. Wagner. 2005. Individual Risk Atitudes: New Evidence from a Large, Representative, ExperimentallyValidated Survey. IZA Discussion Paper No. 1730.

Du Rietz, A. and M. Henrekson. 2000. Testing the Female Underperformance Hypothesis. Small Business Economics 14, 1-10.

Fischer E.M., Reuber A.R. and L.S. Dyke. 1993. A Theoretical Overview and Extension of Research on Sex, Gender and Entrepreneurship. Journal of Business Venturing 8, 151-168.

Hundley, G. 2001. Why women earn less than men in self-employment. Journal of Labor Research 22, 817-829.

Jianakoplos, N. and A. Bernasek. 1998. Are Women More Risk-Averse? Economic Inquiry 36, 620-630.

Kalleberg, A. and K. Leicht. 1991. Gender and Organizational Performance: Determinants of Small Business Survival and Success. Academy of Management Journal 34, 136-161.

Kepler, Erin and Scott Shane. 2007. Are Male and Female Entrepreneurs Really That Different? Working Paper, Small Business Administration, Office of Advocacy: .

Killingsworth, M. R. 1990. Marriage, Labor Supply and Wage Rates: Estimates from a New Econometric Framework. Mimeo.

Loscocco, K. and J. Robinson. 1991. Barriers to women's small-business success in the United States. Gender \& Society 5, 511-532. 
Mayoux, L. 1995. From Vicious to Virtuous Circles? Gender and Micro-Enterprise Development. Occasional Paper 3 ed. United Nations Research Institute for Social Development, UNDP.

McKenzie, D. Mel, S.D. and C. Woodruff. 2007. Returns to Capital in MicroEnterprises: Evidence from a Field Experiment. World Bank Policy Research Paper No. 4230. World Bank, Washington D.C.

McManus, P. 2001. Women's Participation in Self-Employment in Western Industrialized Nations. International Journal of Sociology 31, no. 2:70-97.

Meng, Xing and P. Miller. 2001. Occupation Segregation and its Impact on Gender Wage Gap in China’s Rural Industrial Sector. Oxford Economic Papers 47, no. 1.

Minniti, M., I.E. Allen and N. Langowitz. 2005. Report on Women and Entrepreneurship, Global Entrepreneurship Monitor 2005.

Muravyev, A., D. Schafer and O. Talavera. 2007. Entrepreneurs' Gender and Financial Constraints: Evidence from International Data. Discussion Paper, DIW Berlin, German Institute of Economic Research.

Preston, J.A. 1999. Occupational Segregation: Trends and Explanations: 1970-92. Quarterly Review of Economics and Finance 39: no. 5.

Reynolds P.D., W.D Bygrave., E. Autio, L.W. Cox and M. Hay. 2002. Glohal Entrepreneurship Monitor, 2002, Executive Report.Babson College, London Business School and Kauffman Foundation.

Riding, A. L. and C. S. Swift. 1990. Women Business Owners and Terms of Credit: Some empirical findings of the Canadian Experience. Journal of Business Venturing 5, no. 5, 327-340.

Robb A., and J. Wolken. 2002. Firm, Owner. And Financing Characteristics: Differences Between Male and Female-owned Small Businesses. Working Paper, Federal Reserve Board of Governers: .

Rosa P., S. Carter and D. Hamilton. 1996. Gender as a Determinant of Small Business Performance: Insights from a British Study. Small Business Economics 8, 463-478.

Rosti, L. and F. Chelli. 2005. Gender Discrimination, Entrepreneurial Talent and SelfEmployment. Small Business Economics 24, 131-142.

Storey, D. 2004. Racial and Gender Discrimination in the Micro Firms Credit Market? Small Business Economics 23, no. 5:401-422. 
Storey, D. J. 1994. Understanding the Small Business Sector. London/New York: Routledge.

Verheul, I. and R. Thurik. 2001. Start-Up Capital: "Does Gender Matter?". Small Business Economics 16, 329-345.

Verheul, I., A. van Stel and R. Thurik. 2004. Explaining female and male entrepreneurship across 29 countries .SCALES-paper N200403, EIM Business and Policy Research and SCALES.

Watson, J. 2002. Comparing the Performance of Male- and Female- Controlled Businesses: Relating Outputs to Inputs. Entrepreneurship, Theory \& Practice 26, no. 3:91-100.

Welter, F. and D. Smallbone. 2003. Entrepreneurship and Enterprise Strategies in Transition Economies: An Institutional Perspective. In Small Firms and Economic Development in Developed and Transition Economies: A Reader, edited by David Kirby and Anna Watson. Aldershot, Hampshire, U.K.: Ashgate.

Welter, F., D. Smallbone, E. Aculai, N. Isakova and N. Schakirova. 2003. Female Entrepreneurship in Post Soviet Countries. Edited by John Butler. Greenwich: Information Age.

Wilson, F., J. Kickul, and D. Marlino 2007. Gender, Entrepreneurial Self-Efficacy, and Entrepreneurial Career Intentions: Implications for Entrepreneurship Education. Entrepreneurship Theory and Practice 31 no.3:387-406. 
Table 1: Means of Sample

\begin{tabular}{|c|c|c|c|c|c|}
\hline \multicolumn{6}{|c|}{ Full Sample* } \\
\hline Variable & Obs & Mean & Std. Dev. & Min & $\operatorname{Max}$ \\
\hline Sales & 5106 & 1342.0 & 4767.1 & 2.0 & 82480.0 \\
\hline Fixed Assets (Capital) & 3531 & 643.9 & 2592.8 & 1.0 & 49834.0 \\
\hline Permanent Labor & 7035 & 44.3 & 114.4 & 2.0 & 1700.0 \\
\hline Cost of Material Inputs & 4816 & 647.1 & 2594.6 & 1.0 & 59231.0 \\
\hline Output per worker & 5106 & 32.8 & 38.8 & 0.0 & 615.4 \\
\hline Capital per worker & 3531 & 21.7 & 54.7 & 0.0 & 1522.0 \\
\hline Profits & 4983 & 177.9 & 628.6 & -669.0 & 11852.0 \\
\hline$\%$ with financing from bank & 7,036 & 50.9 & & & \\
\hline \multicolumn{6}{|c|}{ Analytical Sample $e^{\star \star}$} \\
\hline Variable & Obs & Mean & Std. Dev. & Min & $\operatorname{Max}$ \\
\hline Sales & 3334 & 1602.2 & 5162.8 & 7.0 & 82308.0 \\
\hline Fixed Assets (Capital) & 3508 & 619.8 & 2505.8 & 1.0 & 49834.0 \\
\hline Permanent Labor & 3508 & 45.9 & 113.0 & 2.0 & 1600.0 \\
\hline Cost of Material Inputs & 3213 & 805.8 & 2936.9 & 1.0 & 59231.0 \\
\hline Output per worker & 3334 & 38.8 & 41.2 & 0.0 & 416.5 \\
\hline Capital per worker & 3508 & 21.7 & 54.8 & 0.0 & 1522.0 \\
\hline Profits & 3289 & 211.1 & 682.7 & -669.0 & 10604.0 \\
\hline$\%$ with financing from bank & 3508 & 52.1 & & & \\
\hline
\end{tabular}

* Full sample does not include outliers in capital, labor, sales and profits

** Analytical Sample - observations which have information on capital or are not from industries with less than five observations 
Table 2a: Performance Gaps - All countries

\begin{tabular}{|c|c|c|c|c|c|c|c|}
\hline Depen. Var. & Profits & Profits & In Sales & In Sales & Profits & In Sales & In Sales \\
\hline female-owned & $\begin{array}{c}-11.424^{\star \star \star} \\
(2.036)\end{array}$ & $\begin{array}{c}-7.193^{\star \star \star} \\
(2.090)\end{array}$ & $\begin{array}{c}-0.631^{\star \star \star} \\
(0.061)\end{array}$ & $\begin{array}{c}-0.372^{\star \star \star} \\
(0.060)\end{array}$ & $\begin{array}{c}0.834 \\
(1.281)\end{array}$ & $\begin{array}{c}-0.021^{* *} \\
(0.009)\end{array}$ & $\begin{array}{c}-0.020^{\star *} \\
(0.009)\end{array}$ \\
\hline In Sales & & & & & $\begin{array}{c}33.531^{* * *} \\
(0.376)\end{array}$ & 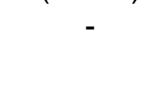 & - \\
\hline InL & & & & & & $\begin{array}{c}0.204^{\star \star \star} \\
(0.006)\end{array}$ & $\begin{array}{c}0.204^{\star \star \star} \\
(0.006)\end{array}$ \\
\hline InK & & & & & & $0.022^{\star * \star}$ & \\
\hline & & & & & & $(0.003)$ & \\
\hline InM & & & & & & $0.795^{\star \star \star}$ & $0.796^{\star \star \star}$ \\
\hline $\begin{array}{l}\text { In(K adj by capacity } \\
\text { utilization) }\end{array}$ & & & & & & & $0.019^{* * \star}$ \\
\hline Country FE & Yes & Yes & Yes & Yes & Yes & Yes & Yes \\
\hline Indus. FE & No & Yes & No & Yes & Yes & Yes & Yes \\
\hline Observations & 3287 & 3287 & 3332 & 3332 & 3287 & 3203 & 3168 \\
\hline R-squared & 0.06 & 0.51 & 0.13 & 0.24 & 0.76 & 0.98 & 0.98 \\
\hline
\end{tabular}

Standard errors in parentheses

* significant at 10\%; ** significant at 5\%; *** significant at 1\% 
Table 2b: Performance Gaps - EU and Non-EU countries

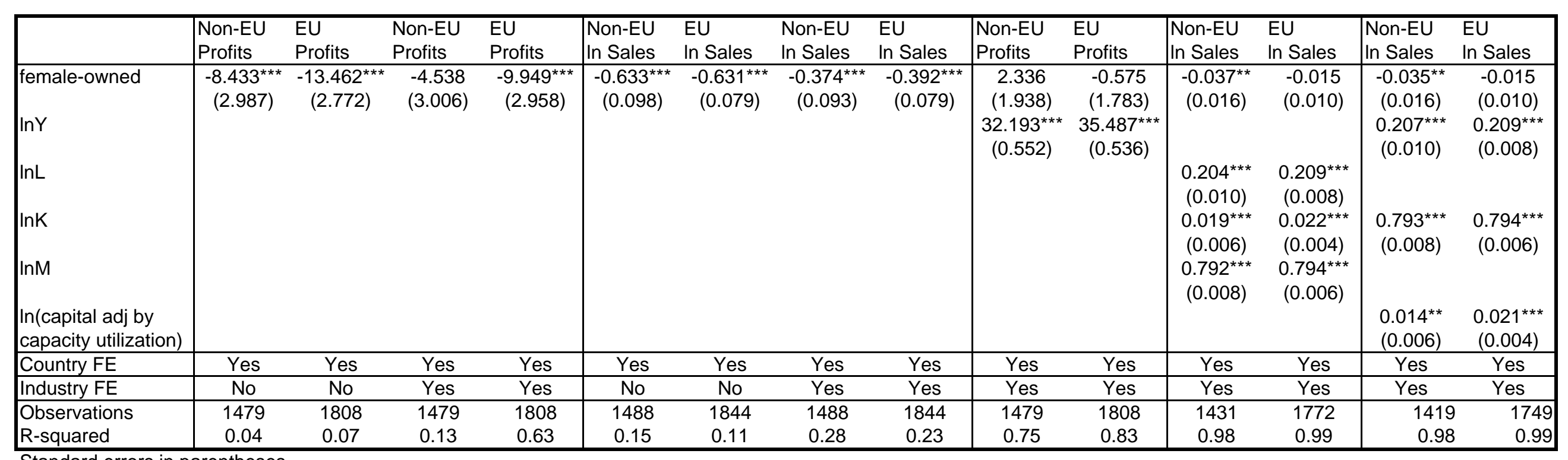

Standard errors in parentheses

* significant at 10\%; ** significant at $5 \%$; ${ }^{* *}$ significant at $1 \%$ 
Table 3: Comparing Mean TFP Estimates for Male and Female Entrepreneurs from Regression with those from Propensity Score Matching

\begin{tabular}{|lcccccc|c|}
\hline Variable: & Sample & Female Mean & Male Mean & Diff. & S.E. & \% Diff. & Regression \\
\hline $\begin{array}{l}\text { TFP Unmatched } \\
\text { With Replacement }\end{array}$ & 5.45 & 6.01 & -0.56 & 0.06 & & \\
$\begin{array}{l}\text { TFP ATT } \\
\begin{array}{l}\text { Without Replacement } \\
\text { TFP ATT }\end{array}\end{array}$ & 5.45 & 5.60 & $-0.15^{* *}$ & 0.45 & -0.027 & \\
\hline
\end{tabular}

Note: Bootstrapped standard errors presented.

\begin{tabular}{|lccc|}
\hline Treatment assignment & Off support & On support & Total \\
\hline Untreated (Male) & 0 & 2,332 & 2,332 \\
Treated (Female) & 2 & 858 & 860 \\
Total & 2 & 3,190 & 3,192 \\
\hline
\end{tabular}

Note: Common support identical for matching with and without replacement 
Table 4a: Returns to Scale - All countries

\begin{tabular}{|c|c|c|}
\hline Depen. Var.: L & Sales N & $\begin{array}{l}\text { Ln Sales } \\
\text { Female }\end{array}$ \\
\hline$\overline{I n L}$ & $\begin{array}{c}0.287^{\star \star \star} \\
(0.038)\end{array}$ & $\begin{array}{c}0.327^{\star \star \star} \\
(0.064)\end{array}$ \\
\hline InK & $\begin{array}{c}0.035^{\star \star \star} \\
(0.007)\end{array}$ & $\begin{array}{c}0.014 \\
(0.009)\end{array}$ \\
\hline InM & $\begin{array}{c}0.702^{\star * \star} \\
(0.037)\end{array}$ & $\begin{array}{c}0.708^{\star \star \star} \\
(0.049)\end{array}$ \\
\hline Sum & 1.024 & 1.049 \\
\hline Observations & 2343 & 860 \\
\hline R-squared & 0.98 & 0.99 \\
\hline
\end{tabular}

Standard errors clustered by industry and shown in parentheses

* significant at 10\%; ** significant at 5\%; *** significant at 1\%

Note: Regression with country and industry fixed effects

Wald Test - Male and Female Entrepreneurs

\begin{tabular}{|c|c|c|c|}
\hline $\begin{array}{l}\text { Ho: } \\
\mathrm{p} \text { value for } 2 \text { tailed test }\end{array}$ & $\begin{array}{c}\text { Men } \\
\alpha_{1}+\alpha_{k}+\alpha_{m}=1 \\
0.000100\end{array}$ & $\begin{array}{c}\text { Women } \\
\beta_{1}+\beta_{\mathrm{k}}+\beta_{\mathrm{m}}=1 \\
0.001100\end{array}$ & $\begin{array}{c}\text { Men = or }>\text { Women } \\
\alpha_{1}+\alpha_{k}+\alpha_{m}=\beta_{l}+\beta_{k}+\beta_{m} \\
0.001900\end{array}$ \\
\hline Ho: & $\alpha_{1}+\alpha_{k}+\alpha_{m}<1$ & $\beta_{1}+\beta_{k}+\beta_{m}<1$ & $\alpha_{1}+\alpha_{k}+\alpha_{m}>\beta_{1}+\beta_{k}+\beta_{m}$ \\
\hline $\begin{array}{l}p \text { value for left tailed test } \\
F \text { (num,den) }\end{array}$ & $\begin{array}{c}0.000057 \\
F(1,32)\end{array}$ & $\begin{array}{c}0.000527 \\
F(1,30)\end{array}$ & $\begin{array}{c}0.000968 \\
F(1,32)\end{array}$ \\
\hline Conclusion & \multicolumn{2}{|c|}{$\begin{array}{l}\text { Null Hypothesis is Rejected } \\
\text { Cannot reject the hypothesis that returns to scale are } \\
\text { greater than one }\end{array}$} & $\begin{array}{l}\text { Null Hypothesis Rejected } \\
\text { Male and Female returns to scale not the same } \\
\text { Cannot reject the hypothesis that returns to scale } \\
\text { for females greater than that for males }\end{array}$ \\
\hline
\end{tabular}


Table 4b: Returns to Scale - EU vs. Non-EU

\begin{tabular}{|c|c|c|c|c|}
\hline$E U=0$ & $\begin{array}{l}\text { Non-EU } \\
\text { Male }\end{array}$ & $\begin{array}{l}\text { Non-EU } \\
\text { Female }\end{array}$ & \begin{tabular}{|l} 
EU \\
Male
\end{tabular} & $\begin{array}{l}\text { EU } \\
\text { Female }\end{array}$ \\
\hline $\mid \operatorname{lnLL}$ & $0.255^{\star \star \star}$ & 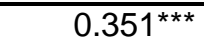 & $0.326^{\star \star \star}$ & $0.300^{\star \star \star \star}$ \\
\hline & (0.031) & $(0.087)$ & $(0.055)$ & $(0.060)$ \\
\hline InKK & $\begin{array}{c}0.037^{\star \star \star *} \\
(0.010)\end{array}$ & $\begin{array}{c}-0.004 \\
(0.027)\end{array}$ & $\begin{array}{c}0.036^{\star * \star *} \\
(0.010)\end{array}$ & $\begin{array}{c}0.021 \\
(0.017)\end{array}$ \\
\hline InMM & 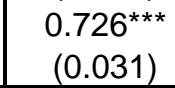 & $\begin{array}{c}0.683^{\star \star \star \star} \\
(0.061)\end{array}$ & $\begin{array}{c}0.671^{\star \star \star} \\
(0.053)\end{array}$ & $\begin{array}{c}0.737^{\star \star \star \star} \\
(0.047)\end{array}$ \\
\hline Sum & 1.018 & 1.03 & 1.033 & 1.058 \\
\hline Observations & 1122 & 309 & 1221 & 551 \\
\hline R-squared & 0.97 & 0.97 & 0.97 & 0.98 \\
\hline
\end{tabular}

Robust standard errors in parentheses

* significant at 10\%; ** significant at 5\%; *** significant at $1 \%$

Wald Test - Male and Female Entrepreneurs - Non EU

\begin{tabular}{|c|c|c|c|}
\hline $\begin{array}{l}\text { Ho: } \\
\mathrm{p} \text { value for } 2 \text { tailed test }\end{array}$ & $\begin{array}{c}\text { Men } \\
\alpha_{1}+\alpha_{k}+\alpha_{m}=1 \\
0.0849 \\
\end{array}$ & $\begin{array}{c}\text { Women } \\
\beta_{1}+\beta_{\mathrm{k}}+\beta_{\mathrm{m}}=1 \\
0.0292\end{array}$ & $\begin{array}{c}\text { Men = or }>\text { Women } \\
\alpha_{1}+\alpha_{k}+\alpha_{m}=\beta_{1}+\beta_{k}+\beta_{m} \\
0.095100\end{array}$ \\
\hline Ho: & $\alpha_{1}+\alpha_{k}+\alpha_{m}<1$ & $\beta_{1}+\beta_{k}+\beta_{m}<1$ & $\alpha_{1}+\alpha_{k}+\alpha_{m}>\beta_{1}+\beta_{k}+\beta_{m}$ \\
\hline $\begin{array}{l}\text { p value for left tailed test } \\
F \text { (num,den) }\end{array}$ & $\begin{array}{c}0.04243564 \\
F(1,32)\end{array}$ & $\begin{array}{c}0.014608 \\
F(1,26)\end{array}$ & $\begin{array}{c}0.047550 \\
F(1,32)\end{array}$ \\
\hline Conclusion & \multicolumn{2}{|c|}{$\begin{array}{l}\text { Null Hypothesis is Rejected } \\
\text { Cannot reject the hypothesis that returns to scale are } \\
\text { greater than one }\end{array}$} & $\begin{array}{l}\text { Null Hypothesis Rejected } \\
\text { Male and Female returns to scale not the same } \\
\text { Cannot reject the hypothesis that returns to scale } \\
\text { for females greater than that for males }\end{array}$ \\
\hline
\end{tabular}

Wald Test - Male and Female Entrepreneurs - EU

\begin{tabular}{|c|c|c|c|}
\hline $\begin{array}{l}\text { Ho: } \\
p \text { value for } 2 \text { tailed test }\end{array}$ & $\begin{array}{c}\text { Men } \\
\alpha_{1}+\alpha_{k}+\alpha_{m}=1 \\
0.0001\end{array}$ & $\begin{array}{c}\text { Women } \\
\beta_{1}+\beta_{\mathrm{k}}+\beta_{\mathrm{m}}=1 \\
0.0004\end{array}$ & $\begin{array}{c}\text { Men = or }>\text { Women } \\
\alpha_{1}+\alpha_{k}+\alpha_{m}=\beta_{1}+\beta_{k}+\beta_{m} \\
0.024300\end{array}$ \\
\hline Ho: & $\alpha_{1}+\alpha_{k}+\alpha_{m}<1$ & $\beta_{1}+\beta_{k}+\beta_{m}<1$ & $\alpha_{1}+\alpha_{k}+\alpha_{m}>\beta_{1}+\beta_{k}+\beta_{m}$ \\
\hline $\begin{array}{l}\text { p value for left tailed test } \\
\text { F(num,den) }\end{array}$ & $\begin{array}{c}0.00006113 \\
F(1,31)\end{array}$ & $\begin{array}{c}0.000218 \\
F(1,27)\end{array}$ & $\begin{array}{c}0.012133 \\
F(1,31)\end{array}$ \\
\hline Conclusion & \multicolumn{2}{|c|}{$\begin{array}{l}\text { Null Hypothesis is Rejected } \\
\text { Cannot reject the hypothesis that returns to scale are } \\
\text { greater than one }\end{array}$} & $\begin{array}{l}\text { Null Hypothesis Rejected } \\
\text { Male and Female returns to scale not the same } \\
\text { Cannot reject the hypothesis that returns to scale } \\
\text { for females greater than that for males }\end{array}$ \\
\hline
\end{tabular}


Table 5: Effect of Industry Characteristics on TFP

\begin{tabular}{|lc|}
\hline \multicolumn{2}{|l|}{ Dependent Var.: In(Sales) } \\
\hline female owned (F) & 0.083 \\
& $(0.066)$ \\
Avg. K in Industry & $-0.021^{\star \star}$ \\
& $(0.008)$ \\
$F^{\star}$ Avg. K in Ind. & $-0.032^{\star \star}$ \\
& $(0.016)$ \\
Avg. L in Industry & $-0.043^{\star \star \star}$ \\
& $(0.012)$ \\
$F^{\star}$ Avg. L in Ind. & 0.025 \\
& $(0.024)$ \\
\hline Observations & 3203 \\
R-squared & 0.98 \\
\hline
\end{tabular}

Standard errors in parentheses: *significant at 10\%;

**significant at $5 \%$; ${ }^{* *}$ significant at $1 \%$

Note: Coefficients from estimating a Cobb-Douglas production 
Table 6a: Financing Constraints on Size (InSales = dependent variable) - All countries

\begin{tabular}{|c|c|c|c|c|c|}
\hline & $\begin{array}{c}(1) \\
\ln Y Y\end{array}$ & $\begin{array}{c}(2) \\
\ln Y Y\end{array}$ & $\begin{array}{l}(3) \\
\ln Y Y\end{array}$ & $\begin{array}{l}(4) \\
\ln Y Y\end{array}$ & $\begin{array}{l}(5) \\
\ln Y Y\end{array}$ \\
\hline Femaleowned & $\begin{array}{c}0.014 \\
(0.009)\end{array}$ & $\begin{array}{l}-0.011 \\
(0.011)\end{array}$ & $\begin{array}{c}0.016 \\
(0.018)\end{array}$ & $\begin{array}{l}-0.008 \\
(0.021)\end{array}$ & $\begin{array}{l}-0.013 \\
(0.033)\end{array}$ \\
\hline Sales in 2002 & $\begin{array}{l}0.982^{\star \star \star} \\
(0.002)\end{array}$ & $\begin{array}{l}0.982^{\star \star \star} \\
(0.002)\end{array}$ & $\begin{array}{l}0.980^{\star \star \star} \\
(0.002)\end{array}$ & $\begin{array}{l}0.983^{\star \star \star} \\
(0.003)\end{array}$ & $\begin{array}{l}0.981^{\star \star \star} \\
(0.003)\end{array}$ \\
\hline Financing from Bank & $\begin{array}{l}0.015^{\star \star} \\
(0.006)\end{array}$ & & & & \\
\hline$F^{\star}$ (financing from Bank) & $\begin{array}{l}-0.015 \\
(0.012)\end{array}$ & & & & \\
\hline $\begin{array}{l}\text { Access to finance is a } \\
\text { constraint to business } \\
\mathrm{F}^{\star} \text { (access to finance is a } \\
\text { constraint to business) }\end{array}$ & & $\begin{array}{l}-0.01 \\
(0.007) \\
0.026^{\star \star} \\
(0.013)\end{array}$ & & & \\
\hline Got a loan recently & & & $\begin{array}{l}0.017^{\star *} \\
(0.007)\end{array}$ & & \\
\hline $\mathrm{F}^{\star}$ (got a loan recently) & & & $\begin{array}{l}-0.021 \\
(0.020)\end{array}$ & & \\
\hline $\begin{array}{l}\text { Need a loan but don't have } \\
\text { it }\end{array}$ & & & $\begin{array}{l}-0.013 \\
(0.009)\end{array}$ & & \\
\hline $\begin{array}{l}F^{*}(\text { need a loan but don't } \\
\text { have it) }\end{array}$ & & & $\begin{array}{c}0.006 \\
(0.022)\end{array}$ & & \\
\hline F*(Don't need a loan) & & & $\begin{array}{l}-0.013 \\
(0.020)\end{array}$ & & \\
\hline Rate of interest & & & & $\begin{array}{c}-0.001 \\
(0.001)\end{array}$ & $\begin{array}{c}-0.001 \\
(0.001)\end{array}$ \\
\hline$F^{\star}($ rate of interest $)$ & & & & $\begin{array}{c}0.000 \\
(0.001)\end{array}$ & $\begin{array}{c}0.000 \\
(0.002)\end{array}$ \\
\hline Value of collateral & & & & & $\begin{array}{c}0.000 \\
(0.001)\end{array}$ \\
\hline $\mathrm{F}^{\star}$ (value of collateral) & & & & & $\begin{array}{c}0.000 \\
(0.001)\end{array}$ \\
\hline Observations & 2510 & 2432 & 2510 & 1259 & 1051 \\
\hline R-squared & 0.99 & 0.99 & 0.99 & 0.99 & 0.99 \\
\hline
\end{tabular}

Note: Robust regressions include country and industry fixed effects

Standard errors in parentheses

* significant at 10\%; ** significant at 5\%; *** significant at $1 \%$ 
Table 6b: Financing Constraints on Size (In Sales= dependent variable) - EU vs. Non-EU countries.

\begin{tabular}{|c|c|c|c|c|c|c|c|c|}
\hline & $\begin{array}{c}\text { Non-EU } \\
\ln Y Y\end{array}$ & $\begin{array}{c}\mathrm{EU} \\
\ln Y Y\end{array}$ & $\begin{array}{c}\text { Non-EU } \\
\text { InYY }\end{array}$ & $\begin{array}{c}\text { EU } \\
\text { InYY }\end{array}$ & $\begin{array}{l}\text { Non-EU } \\
\text { InYY }\end{array}$ & $\begin{array}{c}\text { EU } \\
\text { InYY }\end{array}$ & $\begin{array}{l}\text { Non-EU } \\
\text { InYY }\end{array}$ & $\begin{array}{c}\text { EU } \\
\text { InYY }\end{array}$ \\
\hline femaleowned & $\begin{array}{c}-0.025 \\
(0.017)\end{array}$ & $\begin{array}{c}0.030^{\star \star \star} \\
(0.010)\end{array}$ & $\begin{array}{c}-0.01 \\
(0.020)\end{array}$ & $\begin{array}{c}-0.014 \\
(0.013)\end{array}$ & $\begin{array}{c}0.01 \\
(0.037)\end{array}$ & $\begin{array}{c}0.019 \\
(0.019)\end{array}$ & $\begin{array}{c}0.011 \\
(0.038)\end{array}$ & $\begin{array}{c}0.021 \\
(0.028)\end{array}$ \\
\hline Sales in 2002 & $\begin{array}{c}0.980^{\star * *} \\
(0.003)\end{array}$ & $\begin{array}{c}0.982^{\star \star *} \\
(0.002)\end{array}$ & $\begin{array}{c}0.980^{* * *} \\
(0.003)\end{array}$ & $\begin{array}{c}0.983^{\star * *} \\
(0.002)\end{array}$ & $\begin{array}{c}0.979 * * * \\
(0.003)\end{array}$ & $\begin{array}{c}0.980^{* * *} \\
(0.002)\end{array}$ & $\begin{array}{c}0.984^{\star * *} \\
(0.005)\end{array}$ & $\begin{array}{c}0.980^{\star * *} \\
(0.004)\end{array}$ \\
\hline $\begin{array}{l}\text { Financing from Bank } \\
F^{\star} \text { (financing from Bank) }\end{array}$ & $\begin{array}{c}0.001 \\
(0.011) \\
0.042^{*} \\
(0.022)\end{array}$ & $\begin{array}{c}0.023^{\star * \star} \\
(0.008) \\
-0.043^{\star \star \star} \\
(0.014)\end{array}$ & & & & & & \\
\hline $\begin{array}{l}\text { Access to finance is a } \\
\text { constraint to business } \\
\mathrm{F}^{\star} \text { (access to finance is a } \\
\text { constraint to business })\end{array}$ & & & $\begin{array}{c}-0.002 \\
(0.011) \\
0.014 \\
(0.024)\end{array}$ & $\begin{array}{l}-0.016^{\star} \\
(0.009) \\
0.036^{\star \star} \\
(0.015)\end{array}$ & & & & \\
\hline Got a loan recently & & & & & $\begin{array}{c}0.000 \\
(0.012)\end{array}$ & $\begin{array}{c}0.031^{\star \star \star} \\
(0.009)\end{array}$ & & \\
\hline 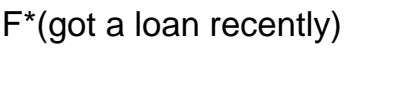 & & & & & $\begin{array}{l}-0.001 \\
(0.040)\end{array}$ & $\begin{array}{c}-0.034 \\
(0.022)\end{array}$ & & \\
\hline $\begin{array}{l}\text { Need a loan but don't have } \\
\text { it }\end{array}$ & & & & & -0.019 & $\begin{array}{l}-0.006 \\
(0.011)\end{array}$ & & \\
\hline $\mathrm{F}^{\star}$ (need a loan but don't & & & & & -0.011 & 0.015 & & \\
\hline have it) & & & & & $(0.043)$ & $(0.024)$ & & \\
\hline$F^{\star}$ (Don't need a loan) & & & & & $\begin{array}{l}-0.038 \\
(0.042)\end{array}$ & $\begin{array}{c}0.002 \\
(0.021)\end{array}$ & & \\
\hline Rate of interest & & & & & & & 0.000 & -0.001 \\
\hline & & & & & & & $(0.001)$ & $(0.001)$ \\
\hline$F^{\star}$ (rate of interest) & & & & & & & $\begin{array}{c}0.000 \\
(0.002)\end{array}$ & $\begin{array}{l}-0.003 \\
(0.002)\end{array}$ \\
\hline Observations & 1167 & 1343 & 1132 & 1300 & 1167 & 1343 & 603 & 655 \\
\hline R-squared & 0.99 & 0.99 & 0.99 & 0.99 & 0.99 & 0.99 & 0.99 & 0.99 \\
\hline
\end{tabular}


Table 7: Effect of Financing Constraints on Total Factor Productivity ${ }^{a}$

\begin{tabular}{|c|c|c|c|c|c|}
\hline & $(1)$ & (2) & (3) & $(4)$ & (5) \\
\hline Femaleowned & $\begin{array}{l}-0.019 \\
(0.012)\end{array}$ & $\begin{array}{l}-0.032^{\star *} \\
(0.015)\end{array}$ & $\begin{array}{l}-0.038^{\star} \\
(0.023)\end{array}$ & $\begin{array}{c}0.002 \\
(0.028)\end{array}$ & $\begin{array}{c}0.002 \\
(0.043)\end{array}$ \\
\hline Financing from Bank & $\begin{array}{l}0.016^{*} \\
(0.009)\end{array}$ & & & & \\
\hline $\mathrm{F}^{\star}$ (financing from Bank) & $\begin{array}{l}-0.003 \\
(0.017)\end{array}$ & & & & \\
\hline $\begin{array}{l}\text { Access to finance is a } \\
\text { constraint to business }\end{array}$ & & $\begin{array}{l}-0.002 \\
(0.010)\end{array}$ & & & \\
\hline $\begin{array}{l}\mathrm{F}^{*}(\text { access to finance is a } \\
\text { constraint to business })\end{array}$ & & $\begin{array}{c}0.019 \\
(0.018)\end{array}$ & & & \\
\hline Need a loan but don't have it & & & $\begin{array}{l}-0.020 \\
(0.012)\end{array}$ & & \\
\hline $\begin{array}{l}F^{*}(\text { need a loan but don't } \\
\text { have it) }\end{array}$ & & & $\begin{array}{c}0.031 \\
(0.028)\end{array}$ & & \\
\hline Got a loan recently & & & $\begin{array}{l}-0.006 \\
(0.010)\end{array}$ & & \\
\hline $\mathrm{F}^{\star}$ (got a loan recently) & & & $\begin{array}{c}0.024 \\
(0.026)\end{array}$ & & \\
\hline F*(Don't need a loan) & & & $\begin{array}{l}0.000 \\
(0.025)\end{array}$ & & \\
\hline Rate of interest on loan & & & & $\begin{array}{c}0.000 \\
(0.001)\end{array}$ & $\begin{array}{c}0.000 \\
(0.001)\end{array}$ \\
\hline $\mathrm{F}^{\star}($ rate of interest on loan $)$ & & & & $\begin{array}{l}-0.002 \\
(0.002)\end{array}$ & $\begin{array}{l}-0.001 \\
(0.002)\end{array}$ \\
\hline Value of collateral & & & & & $\begin{array}{c}0.000 \\
(0.001)\end{array}$ \\
\hline $\mathrm{F}^{\star}$ (value of collateral) & & & & & $\begin{array}{c}0.000 \\
(0.001)\end{array}$ \\
\hline Observations & 3203 & 3096 & 3203 & 1493 & 1238 \\
\hline R-squared & 0.98 & 0.98 & 0.98 & 0.99 & 0.99 \\
\hline
\end{tabular}

${ }^{a}$ Note: Robust regressions where $\ln ($ Sales) is the dependent variable; coefficients on In(labor), In(capital) and In(materials), country and industry fixed effects have been supressed.

Standard errors in parentheses

* significant at $10 \%$; ${ }^{* *}$ significant at $5 \%$; ${ }^{* *}$ significant at $1 \%$ 
Table 8: Constraints on the use of inputs (dependent variable is $\ln (K / L)$ )

\begin{tabular}{|c|c|c|c|c|c|c|c|c|}
\hline & (1) & (2) & (3) & (4) & (5) & (6) & (7) & (8) \\
\hline Femaleowned & $\begin{array}{l}-0.021 \\
(0.046)\end{array}$ & $\begin{array}{l}-0.048 \\
(0.047)\end{array}$ & $\begin{array}{l}-0.104 \\
(0.166)\end{array}$ & $\begin{array}{l}-0.068 \\
(0.065)\end{array}$ & $\begin{array}{l}-0.012 \\
(0.079)\end{array}$ & $\begin{array}{l}-0.105 \\
(0.122)\end{array}$ & $\begin{array}{c}-0.09 \\
(0.148)\end{array}$ & $\begin{array}{c}0.068 \\
(0.225)\end{array}$ \\
\hline In(sales) & & $\begin{array}{l}-0.078^{* \star *} \\
(0.014)\end{array}$ & $\begin{array}{l}-0.081^{* * *} \\
(0.015)\end{array}$ & $\begin{array}{c}-0.086^{\star * *} \\
(0.014)\end{array}$ & $\begin{array}{c}-0.082^{\star \star \star} \\
(0.014)\end{array}$ & $\begin{array}{l}-0.104^{\star \star \star} \\
(0.014)\end{array}$ & $\begin{array}{l}-0.093^{\star \star *} \\
(0.020)\end{array}$ & $\begin{array}{c}-0.106^{\star \star \star} \\
(0.022)\end{array}$ \\
\hline$F^{*} \ln ($ sales $)$ & & & $\begin{array}{c}0.01 \\
(0.028)\end{array}$ & & & & & \\
\hline Financing from Bank & & & & $\begin{array}{l}0.125^{\star \star \star} \\
(0.047)\end{array}$ & & & & \\
\hline$F^{*}$ (financing from Bank) & & & & $\begin{array}{c}0.049 \\
(0.089)\end{array}$ & & & & \\
\hline $\begin{array}{l}\text { Access to finance is a } \\
\text { constraint to business }\end{array}$ & & & & & $\begin{array}{l}-0.015 \\
(0.051)\end{array}$ & & & \\
\hline $\begin{array}{l}\mathrm{F}^{\star} \text { (access to finance is a } \\
\text { constraint to business })\end{array}$ & & & & & $\begin{array}{l}-0.042 \\
(0.096)\end{array}$ & & & \\
\hline $\begin{array}{l}\text { Need a loan but don't have } \\
\text { it }\end{array}$ & & & & & & $\begin{array}{l}-0.04 \\
(0.065)\end{array}$ & & \\
\hline $\mathrm{F}^{\star}$ (need a loan but don't & & & & & & $\begin{array}{c}0.074 \\
(0.151)\end{array}$ & & \\
\hline Got a loan recently & & & & & & $\begin{array}{l}0.206^{\star \star \star} \\
(0.053)\end{array}$ & & \\
\hline$F^{\star}$ (got a loan recently) & & & & & & $\begin{array}{c}0.105 \\
(0.140)\end{array}$ & & \\
\hline$F^{\star}$ (Don't need a loan) & & & & & & $\begin{array}{l}-0.013 \\
(0.136)\end{array}$ & & \\
\hline Rate of interest on loan & & & & & & & $\begin{array}{l}-0.006 \\
(0.007)\end{array}$ & $\begin{array}{l}-0.006 \\
(0.007)\end{array}$ \\
\hline $\mathrm{F}^{\star}$ (rate of interest on loan) & & & & & & & $\begin{array}{c}0.004 \\
(0.010)\end{array}$ & $\begin{array}{c}0.006 \\
(0.011)\end{array}$ \\
\hline Value of collateral & & & & & & & & $\begin{array}{c}0.001 \\
(0.001)\end{array}$ \\
\hline $\mathrm{F}^{\star}$ (value of collateral) & & & & & & & & $\begin{array}{l}-0.001 \\
(0.001)\end{array}$ \\
\hline Observations & 3506 & 3332 & 3332 & 3332 & 3219 & 3332 & 1550 & 1289 \\
\hline R-squared & 0.35 & 0.37 & 0.37 & 0.37 & 0.37 & 0.37 & 0.41 & 0.44 \\
\hline
\end{tabular}

Note: Robust regressions include country and industry fixed effects

Standard errors in parentheses

* significant at $10 \%$; ** significant at $5 \%$; *** significant at $1 \%$ 
Table 9: Within and Between Industry Variance for Entrepreneurs

\begin{tabular}{|c|c|c|c|c|c|}
\hline \multicolumn{6}{|c|}{ Analysis of Variance for Ln(sales) - Male Entrepreneurs } \\
\hline Source & SS & $\mathrm{df}$ & MS & $\mathrm{F}$ & Prob > F \\
\hline Between groups & 533.00 & 32.00 & 16.66 & 7.13 & 0.000 \\
\hline Within groups & 5634.99 & 2411.00 & 2.34 & & \\
\hline Total & 6167.99 & 2443.00 & 2.52 & & \\
\hline \multirow{2}{*}{\multicolumn{2}{|c|}{ Bartlett's test for equal variance }} & chi2 (89) & 53.643 & & \\
\hline & & Prob>chi2 & 0.010 & & \\
\hline \multicolumn{6}{|c|}{ Analysis of Variance for Ln(sales) - Female Entrepreneurs } \\
\hline Source & SS & df & MS & $\mathrm{F}$ & \multirow{4}{*}{$\begin{array}{c}\text { Prob > F } \\
0.000\end{array}$} \\
\hline Between groups & 596.28 & 30.00 & 19.88 & 10.03 & \\
\hline Within groups & 1698.56 & 857.00 & 1.98 & & \\
\hline Total & 2294.84 & 887.00 & 2.59 & & \\
\hline \multirow{2}{*}{\multicolumn{2}{|c|}{ Bartlett's test for equal variance }} & chi2(81) & 39.104 & & \\
\hline & & Prob>chi2 & 0.036 & & \\
\hline
\end{tabular}


Figure 1: Share of Female Entrepreneurs by Country

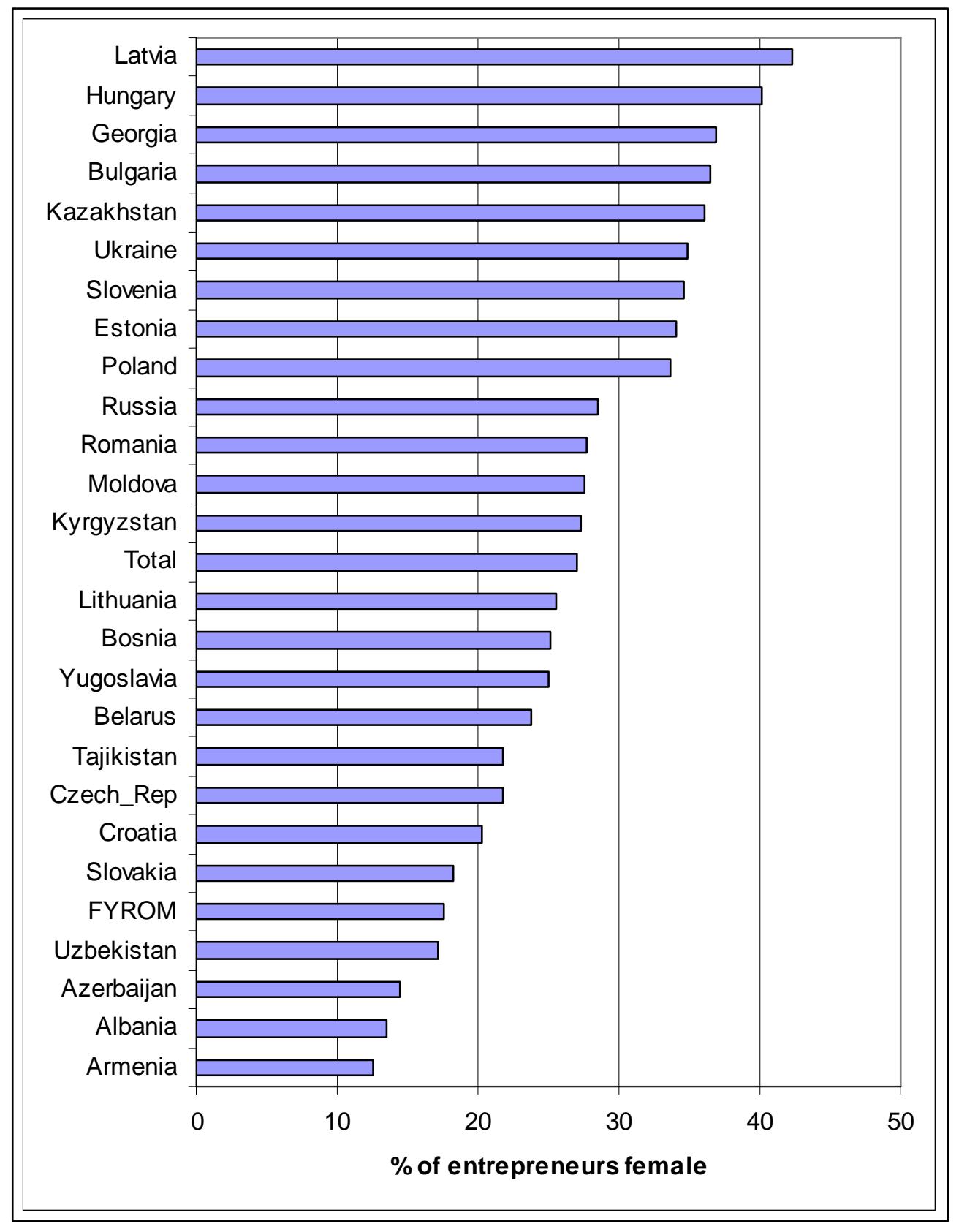


Figure 2: Share of Female v. Male Entreprenuers by Size of Firm (no. of Employees)

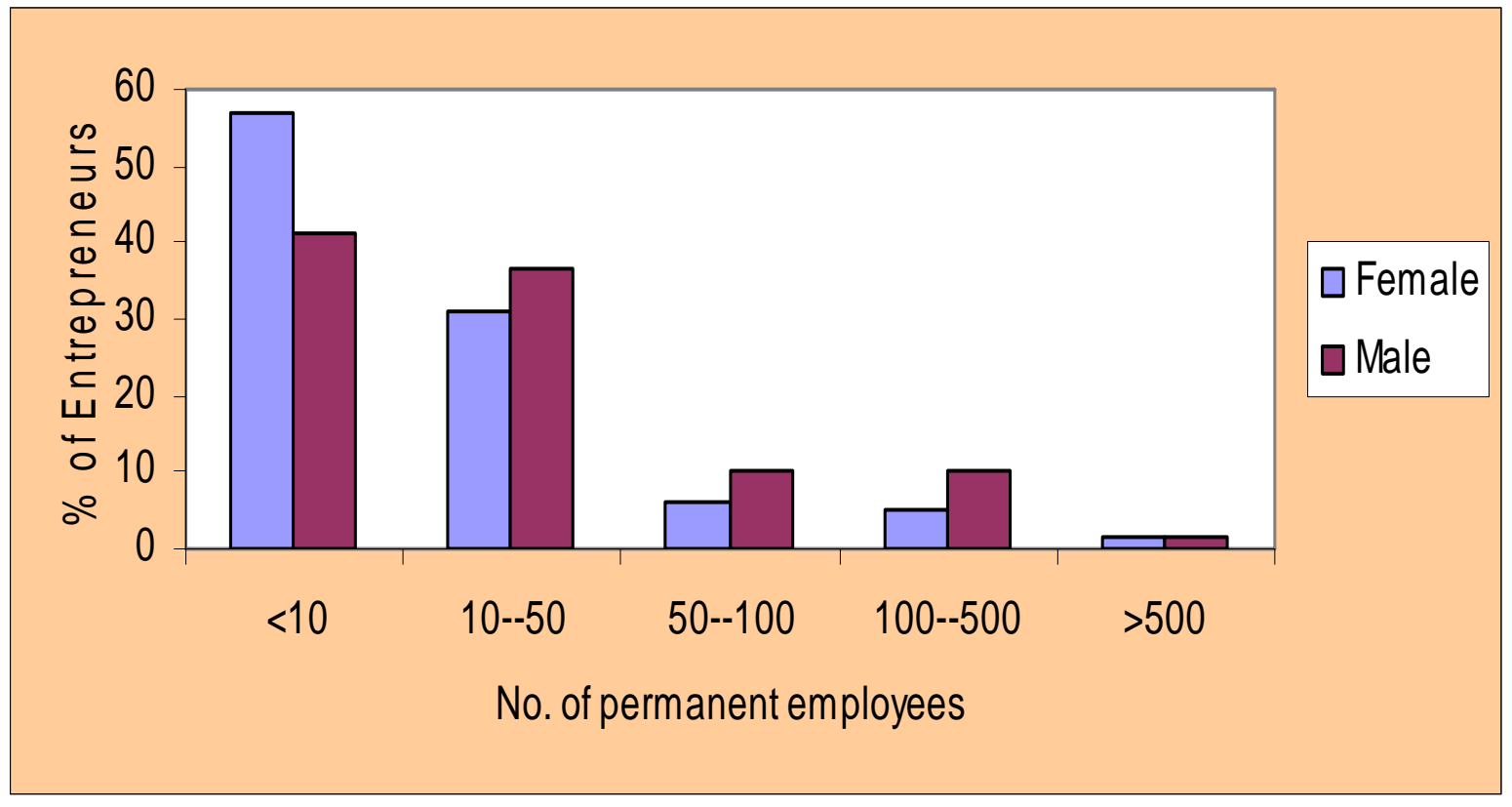




\section{Figure 3: Concentration of female entrepreneurs by industry}

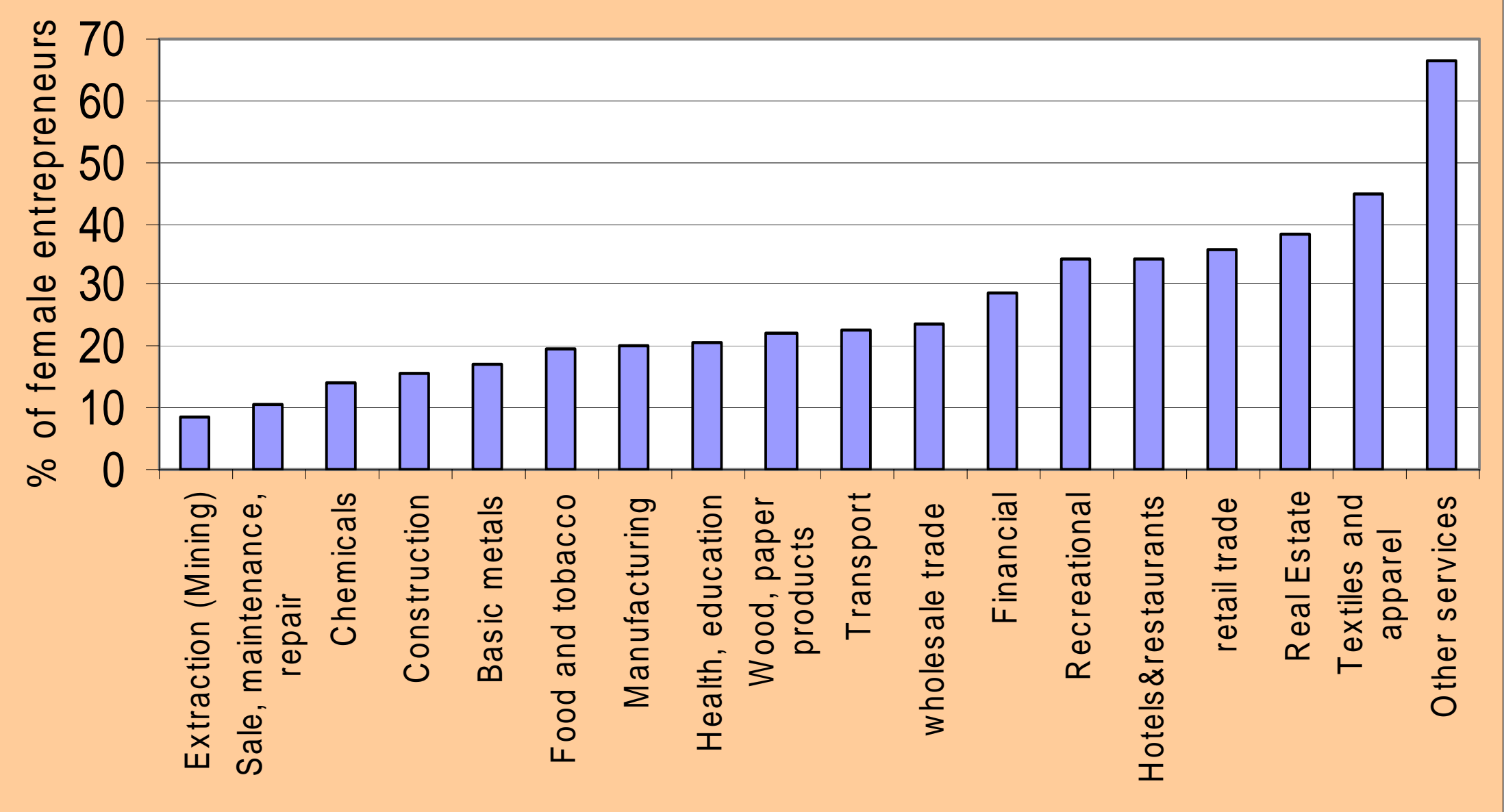


Fig 4: Plots of the Share of Female Entrepreneurs in an Industry v. Industry Characterisitics
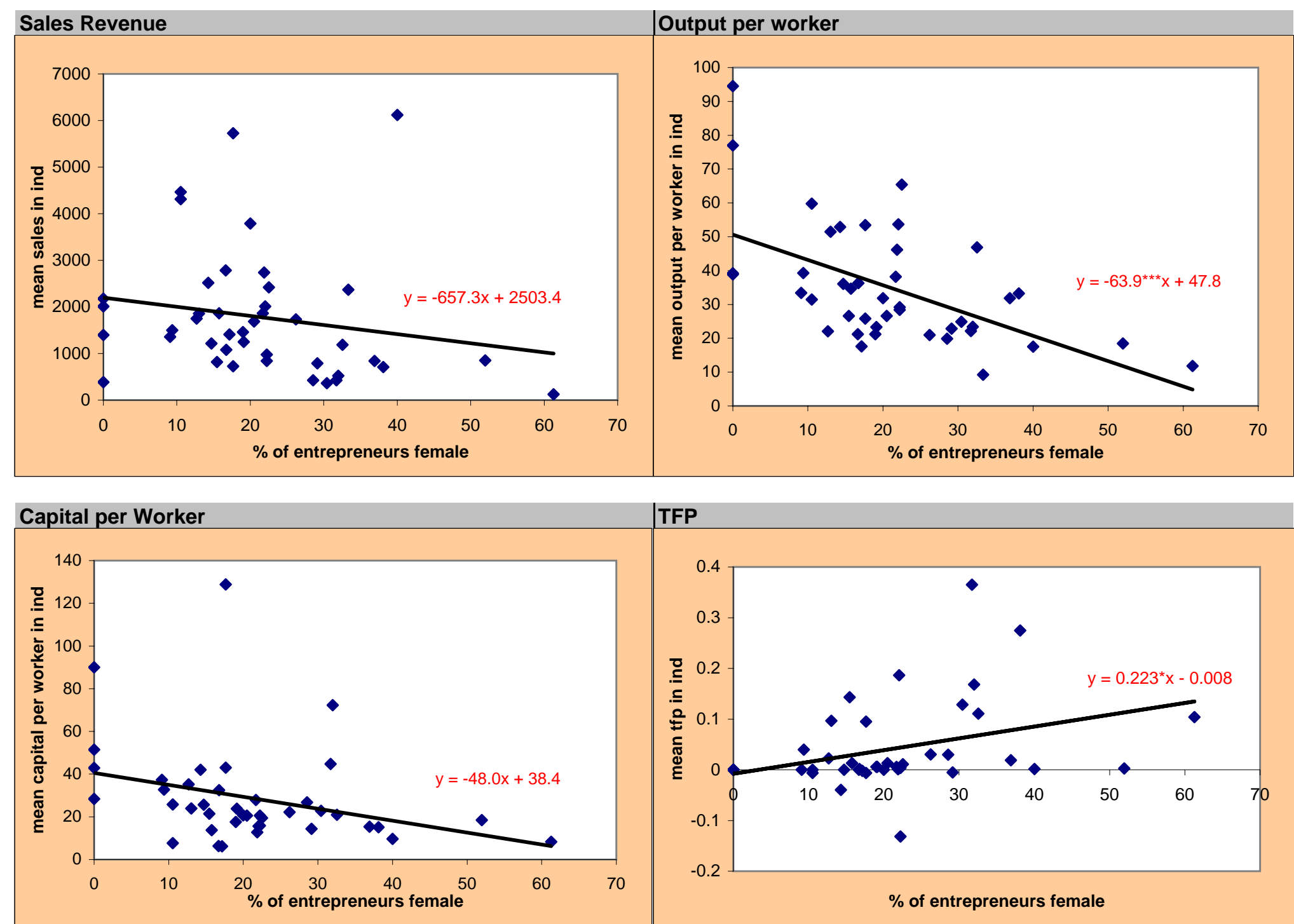
Fig 5: Kernel Density Estimates of TFP for Male and Female Entrepreneurs

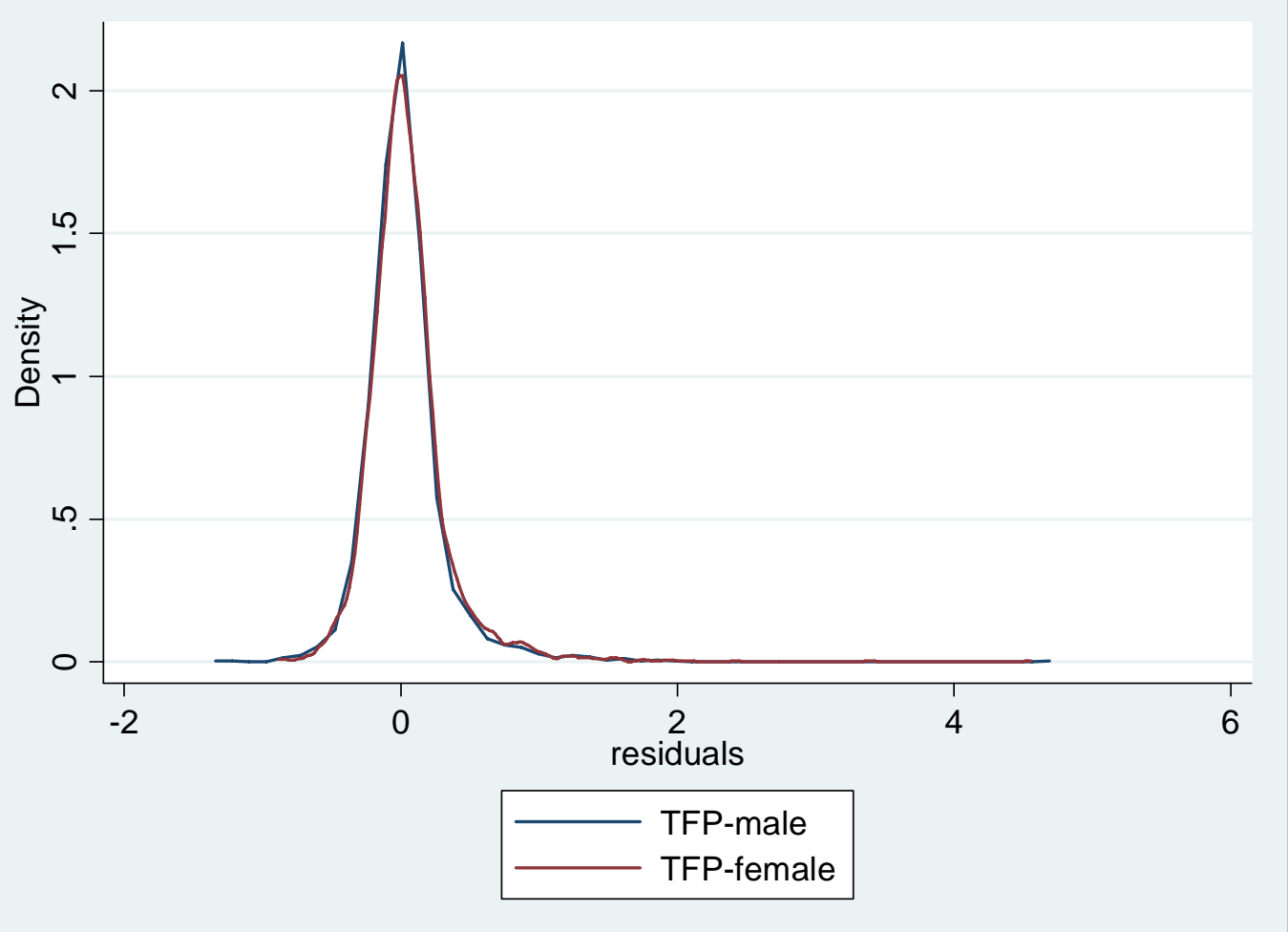

Note: Kernel density calculated using Epanechnikov kernel function.

Note: Country and industry fixed effects used in TFP calculation. 
Table A1: Returns to Scale

\begin{tabular}{|ccc|cc|}
\hline & \multicolumn{2}{c|}{ Services } & \multicolumn{2}{c|}{ Manufacturing } \\
& In Sales & Ln Sales & In Sales & Ln Sales \\
Depen. Var.: & Male & Female & Male & Female \\
\hline InL & $0.388^{\star \star \star}$ & $0.420^{\star \star \star}$ & $0.200^{\star \star \star}$ & $0.209^{\star \star \star}$ \\
& $(0.072)$ & $(0.110)$ & $(0.011)$ & $(0.013)$ \\
InK & $0.039^{\star \star \star}$ & 0.015 & $0.027^{\star \star \star}$ & $0.016^{\star}$ \\
& $(0.011)$ & $(0.014)$ & $(0.007)$ & $(0.008)$ \\
InM & $0.617^{\star \star \star}$ & $0.649^{\star \star \star}$ & $0.785^{\star \star \star}$ & $0.802^{\star \star \star}$ \\
& $(0.067)$ & $(0.075)$ & $(0.012)$ & $(0.010)$ \\
\hline Sum & 1.044 & 1.084 & 1.012 & 1.027 \\
\hline Observations & 997 & 479 & 1346 & 381 \\
R-squared & 0.95 & 0.96 & 0.98 & 0.99 \\
\hline
\end{tabular}

Standard errors clustered by industry and shown in parentheses

* significant at $10 \%$; ** significant at $5 \%$; *** significant at $1 \%$

Note: Reg with country and industry fixed effects

\section{Wald Test - Mfg and Services Male Entrepreneurs}

\begin{tabular}{|c|c|c|c|}
\hline $\begin{array}{l}\text { Ho: } \\
p \text { value for } 2 \text { tailed test }\end{array}$ & $\begin{array}{c}\text { Services } \\
\alpha_{1}+\alpha_{k}+\alpha_{m}=1 \\
0.001700\end{array}$ & $\begin{array}{c}\text { Mfg } \\
\beta_{1}+\beta_{k}+\beta_{m}=1 \\
0.002500\end{array}$ & $\begin{array}{c}\text { Mfg }=\text { or }>\text { Services } \\
\alpha_{1}+\alpha_{k}+\alpha_{m}=\beta_{1}+\beta_{k}+\beta_{m}\end{array}$ \\
\hline & $\alpha_{1}+\alpha_{k}+\alpha_{m}<1$ & $\beta_{\mathrm{l}}+\beta_{\mathrm{k}}+\beta_{\mathrm{m}}<1$ & $\alpha_{1}+\alpha_{k}+\alpha_{m}>\beta_{1}+\beta_{k}+\beta_{m}$ \\
\hline$p$ value for left tailed test & 0.000827 & 0.001231 & 0.995894 \\
\hline F(num,den) & $F(1,12)$ & $F(1,19)$ & $F(1,32)$ \\
\hline Conclusion & \multicolumn{2}{|l|}{ Null Hypothesis is Rejected } & Null Hypothesis Rejected \\
\hline & \multicolumn{2}{|c|}{$\begin{array}{l}\text { Cannot reject the hypothesis that returns to scale are } \\
\text { greater than one }\end{array}$} & $\begin{array}{l}\text { Mfg and Services returns to scale } \\
\text { not the same } \\
\text { Cannot reject the hypothesis that } \\
\text { returns to scale for services } \\
\text { greater than that for } \\
\text { manufacturing }\end{array}$ \\
\hline
\end{tabular}


Wald Test - Mfg and Services Female Entrepreneurs

\begin{tabular}{|c|c|c|c|}
\hline $\begin{array}{l}\text { Ho: } \\
\text { p value for } 2 \text { tailed test }\end{array}$ & $\begin{array}{c}\text { Services } \\
\alpha_{1}+\alpha_{k}+\alpha_{m}=1 \\
0.035400\end{array}$ & $\begin{array}{c}\mathrm{Mfg} \\
\beta_{\mathrm{I}}+\beta_{\mathrm{k}}+\beta_{\mathrm{m}}=1 \\
0.006900\end{array}$ & $\begin{array}{c}\text { Mfg }=\text { or }>\text { Services } \\
\alpha_{1}+\alpha_{k}+\alpha_{m}=\beta_{1}+\beta_{k}+\beta_{m} \\
0.073000\end{array}$ \\
\hline & $\alpha_{1}+\alpha_{k}+\alpha_{m}<1$ & $\beta_{1}+\beta_{k}+\beta_{m}<1$ & $\alpha_{l}+\alpha_{k}+\alpha_{m}>\beta_{l}+\beta_{k}+\beta_{m}$ \\
\hline$\frac{p \text { value for left tailed test }}{F(\text { num,den) }}$ & $\frac{0.017720}{F(1,11)}$ & $\frac{0.003471}{F(1,18)}$ & $\frac{0.963525}{F(1,30)}$ \\
\hline Conclusion & \multicolumn{2}{|l|}{ Null Hypothesis is Rejected } & Null Hypothesis Rejected \\
\hline & \multicolumn{2}{|c|}{$\begin{array}{l}\text { Cannot reject the hypothesis that returns to scale are } \\
\text { greater than one }\end{array}$} & $\begin{array}{l}\text { Mfg and Services returns to scale } \\
\text { not the same } \\
\text { Cannot reject the hypothesis that } \\
\text { returns to scale for services } \\
\text { greater than that for } \\
\text { manufacturing }\end{array}$ \\
\hline
\end{tabular}

\section{Wald Test - Male and Female Entrepreneurs (Mfg and Services)}

\begin{tabular}{|c|c|c|}
\hline $\begin{array}{l}\text { Ho: } \\
p \text { value for } 2 \text { tailed test }\end{array}$ & $\begin{array}{c}\text { Mfg } \\
\text { Male }=\text { or }>\text { Female } \\
\alpha_{1}+\alpha_{k}+\alpha_{m}=\beta_{l}+\beta_{k}+\beta_{m} \\
0.198600\end{array}$ & $\begin{array}{c}\text { Services } \\
\text { Male }=\text { or }>\text { Female } \\
\alpha_{1}+\alpha_{k}+\alpha_{m}=\beta_{1}+\beta_{k}+\beta_{m} \\
0.173700\end{array}$ \\
\hline $\begin{array}{l}\text { Ho: } \\
p \text { value for left tailed test }\end{array}$ & $\begin{array}{c}\alpha_{1}+\alpha_{k}+\alpha_{m}>\beta_{l}+\beta_{k}+\beta_{m} \\
0.099321\end{array}$ & $\begin{array}{c}\alpha_{1}+\alpha_{k}+\alpha_{m}>\beta_{1}+\beta_{k}+\beta_{m} \\
0.086873\end{array}$ \\
\hline $\mathrm{F}$ (num,den) & $F(1,32)$ & $F(1,12)$ \\
\hline Conclusion & $\begin{array}{l}\text { Null Hypothesis Rejected } \\
\text { Male and female returns to } \\
\text { scale not the same } \\
\text { Cannot reject the hypothesis } \\
\text { (at } 10 \% \text { level) that returns to } \\
\text { scale for females greater than } \\
\text { that for males }\end{array}$ & $\begin{array}{l}\text { Null Hypothesis Rejected } \\
\text { Male and female returns to scale } \\
\text { not the same } \\
\text { Cannot reject the hypothesis that } \\
\text { returns to scale for females is } \\
\text { greater than that for males }\end{array}$ \\
\hline
\end{tabular}


Table A2: Means and St. Dev. of Variables by Gender (for analytical sample)

\begin{tabular}{|c|c|c|c|c|c|c|c|}
\hline Variable & & Obs & Mean & Std. Dev. & Min & $\operatorname{Max}$ & $\begin{array}{c}\text { M-F (Significance of } \\
\text { Difference) }\end{array}$ \\
\hline \multirow[t]{2}{*}{$\ln$ (sales) } & Male & 2444 & 6.01 & 1.59 & 2.08 & 11.32 & \\
\hline & Female & 888 & 5.46 & 1.61 & 2.20 & 11.32 & $Y$ at 0.01 level \\
\hline \multirow[t]{2}{*}{$\ln$ (labor) } & Male & 2568 & 2.89 & 1.32 & 1.10 & 7.38 & \\
\hline & Female & 938 & 2.44 & 1.25 & 1.10 & 7.20 & $Y$ at 0.01 level \\
\hline \multirow[t]{2}{*}{ In(capital) } & Male & 2568 & 4.92 & 1.68 & 0.69 & 10.82 & \\
\hline & Female & 938 & 4.44 & 1.70 & 0.69 & 10.35 & $Y$ at 0.01 level \\
\hline \multirow[t]{2}{*}{ In(materials) } & Male & 2350 & 5.09 & 1.74 & 0.69 & 10.60 & \\
\hline & Female & 861 & 4.51 & 1.80 & 0.69 & 10.99 & $Y$ at 0.01 level \\
\hline \multirow[t]{2}{*}{ profits } & Male & 2411 & 227.30 & 686.56 & -669.00 & 10540 & \\
\hline & Female & 876 & 166.14 & 670.78 & -75.00 & 10604 & $Y$ at 0.05 level \\
\hline \multirow[t]{2}{*}{ profits/sales } & Male & 2411 & 0.14 & 0.09 & -0.56 & 0.60 & \\
\hline & Female & 876 & 0.15 & 0.10 & -0.29 & 0.94 & $Y$ at 0.05 level \\
\hline \multirow{2}{*}{ In(capital per worker) } & Male & 2568 & 2.12 & 1.43 & -3.18 & 7.33 & \\
\hline & Female & 938 & 2.12 & 1.40 & -2.81 & 6.86 & $\mathrm{~N}$ \\
\hline financing from bank & Male & 2568 & 0.53 & 0.50 & 0 & 1 & \\
\hline (local or foreign or state owned) & Female & 938 & 0.51 & 0.50 & 0 & 1 & $\mathrm{~N}$ \\
\hline financing from internal sources & Male & 2019 & 73.89 & 36.60 & 0 & 100 & \\
\hline (internal+family/friends+money lenders \& other informal) & Female & 674 & 78.16 & 35.01 & 0 & 100 & $Y$ at 0.01 level \\
\hline financing from external sources & Male & 2019 & 23.13 & 34.87 & 0 & 100 & \\
\hline (Banks+Credit cards+Leasing) & Female & 674 & 17.23 & 31.82 & 0 & 100 & $\mathrm{~N}$ \\
\hline got a loan recently & Male & 2568 & 0.43 & 0.50 & 0 & 1 & \\
\hline (within last 12 months) & Female & 938 & 0.37 & 0.48 & 0 & 1 & $\mathrm{Y}$ at 0.01 level \\
\hline \multirow[t]{2}{*}{ do not need a loan } & Male & 2568 & 0.26 & 0.44 & 0 & 1 & \\
\hline & Female & 938 & 0.27 & 0.44 & 0 & 1 & $\mathrm{~N}$ \\
\hline \multirow[t]{2}{*}{ need a loan but do not have it } & Male & 2568 & 0.19 & 0.40 & 0 & 1 & \\
\hline & Female & 938 & 0.25 & 0.43 & 0 & 1 & $Y$ at 0.01 level \\
\hline \multirow[t]{2}{*}{ access to finance is a constraint to business } & Male & 2489 & 0.67 & 0.47 & 0 & 1 & \\
\hline & Female & 893 & 0.66 & 0.47 & 0 & 1 & $\mathrm{~N}$ \\
\hline \multirow[t]{2}{*}{ rate of interest on loan } & Male & 1228 & 13.47 & 6.85 & 0.70 & 70 & \\
\hline & Female & 394 & 13.39 & 6.67 & 0.50 & 36 & $\mathrm{~N}$ \\
\hline \multirow[t]{2}{*}{ value of collateral for loan } & Male & 1062 & 163.20 & 75.74 & 12.00 & 600 & \\
\hline & Female & 336 & 173.15 & 76.21 & 30.00 & 500 & $Y$ at 0.05 level \\
\hline \multirow[t]{2}{*}{ capacity utilitzation (\%) } & Male & 2546 & 81.13 & 19.54 & 5 & 100 & \\
\hline & Female & 923 & 82.36 & 19.35 & 10 & 100 & $\mathrm{Y}$ at 0.1 level \\
\hline \multirow{2}{*}{ age of firm } & Male & 2566 & 2.36 & 0.61 & 1.39 & 5.19 & \\
\hline & Female & 936 & 2.31 & 0.60 & 1.39 & 4.96 & $Y$ at 0.05 level \\
\hline
\end{tabular}


Table A3: Sources of Finance by Gender

\begin{tabular}{|lccc|ccc|}
\hline Male & \multicolumn{3}{c|}{ Working Capital } & \multicolumn{3}{c|}{ New Investment } \\
Variable & Obs & Mean & Std. Dev. & Obs & Mean & Std. Dev. \\
\hline Internal funds/ Retained earnings & 2553 & 67.8 & 37.6 & 2039 & 64.3 & 40.5 \\
Equity (i.e. issue of new share) & 2553 & 5.2 & 18.7 & 2039 & 4.9 & 19.4 \\
Borrowing from local private commercial & 2553 & 9.6 & 21.5 & 2039 & 13.2 & 27.9 \\
Borrowing from foreign banks & 2553 & 1.0 & 6.8 & 2039 & 1.7 & 10.7 \\
Borrowing from state owned banks & 2553 & 2.0 & 10.2 & 2039 & 2.2 & 12.1 \\
Loans from family/friends & 2553 & 4.1 & 14.5 & 2039 & 3.6 & 14.2 \\
Money lenders and other informal sourc & 2553 & 1.2 & 7.4 & 2039 & 1.2 & 8.1 \\
Trade credit from suppliers & 2553 & 4.2 & 14.1 & 2039 & 1.0 & 6.9 \\
Trade credit from customers & 2553 & 1.0 & 6.6 & 2039 & 0.4 & 4.2 \\
Credit Cards & 2553 & 0.6 & 5.4 & 2039 & 0.4 & 4.5 \\
Leasing arrangement & 2553 & 1.9 & 8.9 & 2039 & 5.5 & 18.8 \\
The government & 2553 & 0.4 & 4.9 & 2039 & 0.2 & 2.7 \\
Other & 2553 & 1.0 & 9.0 & 2039 & 1.4 & 11.0 \\
\hline
\end{tabular}

\begin{tabular}{|lccc|ccc|}
\hline Female & \multicolumn{3}{c|}{ Working Capital } & \multicolumn{3}{c|}{ New Investment } \\
Variable & Obs & Mean & Std. Dev. & Obs & Mean & Std. Dev. \\
\hline Internal funds/ Retained earnings & 925 & 71.7 & 38.2 & 679 & 68.5 & 40.2 \\
Equity (i.e. issue of new share) & 925 & 5.3 & 19.9 & 679 & 4.9 & 19.4 \\
Borrowing from local private commercial & 925 & 6.4 & 18.4 & 679 & 9.3 & 24.5 \\
Borrowing from foreign banks & 925 & 1.0 & 8.0 & 679 & 1.4 & 10.2 \\
Borrowing from state owned banks & 925 & 1.5 & 9.0 & 679 & 2.0 & 11.5 \\
Loans from family/friends & 925 & 3.4 & 13.3 & 679 & 4.1 & 16.0 \\
Money lenders and other informal sourc & 925 & 0.4 & 3.8 & 679 & 0.6 & 4.5 \\
Trade credit from suppliers & 925 & 5.2 & 16.2 & 679 & 1.6 & 8.4 \\
Trade credit from customers & 925 & 1.2 & 8.1 & 679 & 0.7 & 6.1 \\
Credit Cards & 925 & 0.5 & 4.5 & 679 & 0.2 & 4.0 \\
Leasing arrangement & 925 & 1.5 & 6.8 & 679 & 4.3 & 16.9 \\
The government & 925 & 0.4 & 4.9 & 679 & 0.4 & 4.1 \\
Other & 925 & 1.4 & 11.2 & 679 & 1.9 & 13.2 \\
\hline
\end{tabular}


A4. Female Education and Entrepreneurship in ECA

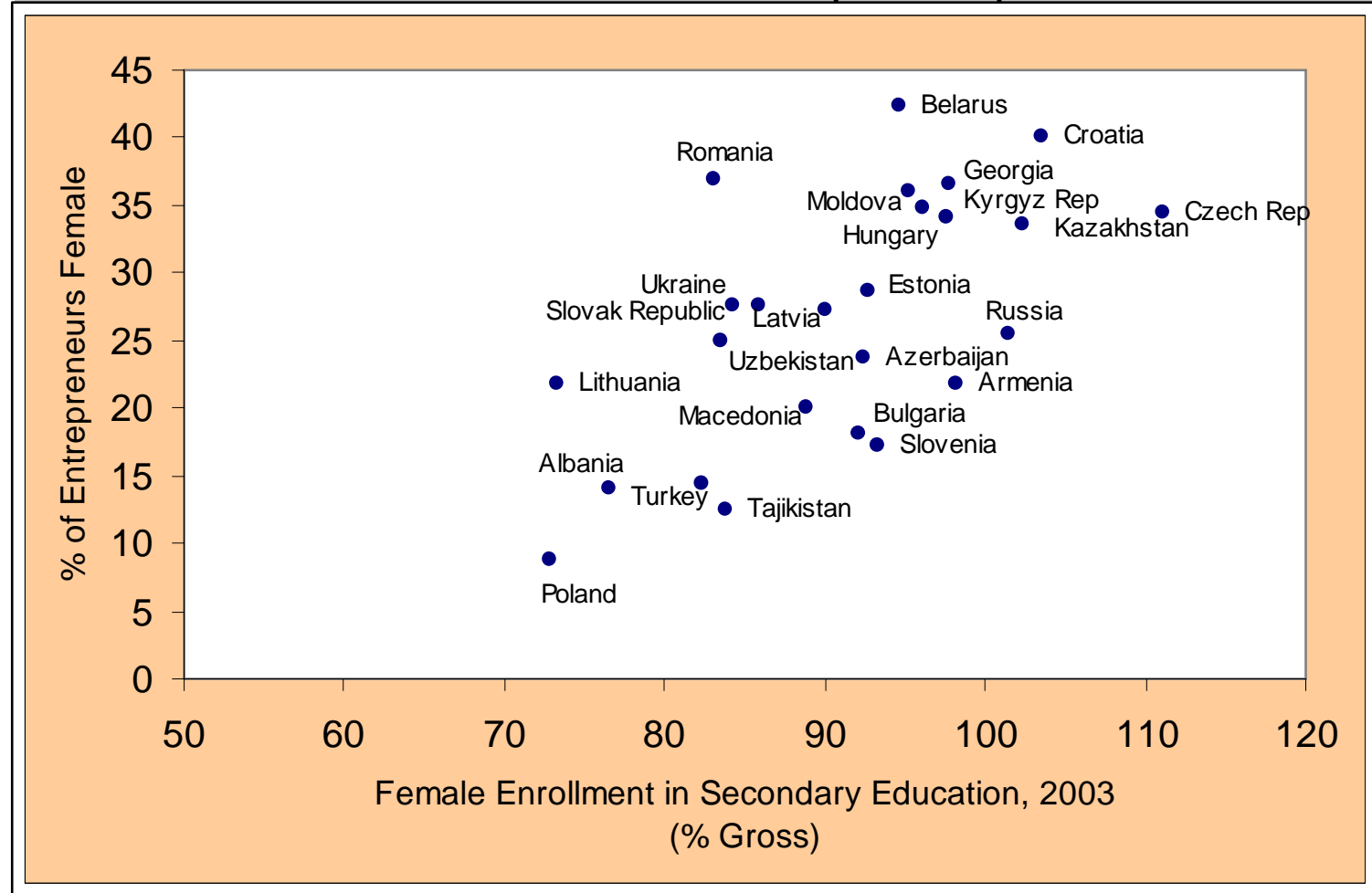

Data for Secondary Education from World Development Indicators 2006

Data for Female Entrepreneurship from BEEPS 2005 